\title{
Peripheral Neuropathy under Oncologic Therapies: A Literature Review on Pathogenetic Mechanisms
}

\author{
Mariarita Laforgia ${ }^{1}$, Carmelo Laface ${ }^{2,3}\left(\mathbb{D}\right.$, Concetta Calabrò ${ }^{1}$, Simona Ferraiuolo ${ }^{1}$, Valentina Ungaro ${ }^{1}$, \\ Domenico Tricarico ${ }^{4}$, Cosmo Damiano Gadaleta ${ }^{2}$, Patrizia Nardulli ${ }^{1} \mathbb{D}$ and Girolamo Ranieri ${ }^{2, *}$ \\ 1 Pharmacy Unit, IRCCS Istituto Tumori “Giovanni Paolo II”, Viale Orazio Flacco 65, 70124 Bari, Italy; \\ m.laforgia@oncologico.bari.it (M.L.); concetta.calabro@oncologico.bari.it (C.C.); \\ s.ferraiuolo@oncologico.bari.it (S.F.); valentina_ungaro@hotmail.com (V.U.); \\ p.nardulli@oncologico.bari.it (P.N.) \\ 2 Interventional and Medical Oncology Unit, IRCCS Istituto Tumori “Giovanni Paolo II", Viale Orazio Flacco 65, \\ 70124 Bari, Italy; carmelo.laface@gmail.com (C.L.); c.gadaleta@oncologico.bari.it (C.D.G.) \\ 3 Department of Biomedical Sciences and Human Oncology, University of Bari 'Aldo Moro', 70121 Bari, Italy \\ 4 Section of Pharmacology, Department of Pharmacy-Pharmaceutical Sciences, University of Bari, \\ Via Orabona 4, 70125 Bari, Italy; domenico.tricarico@uniba.it \\ * Correspondence: giroran@tiscali.it
}

Citation: Laforgia, M.; Laface, C.; Calabrò, C.; Ferraiuolo, S.; Ungaro, V.; Tricarico, D.; Gadaleta, C.D.; Nardulli, P.; Ranieri, G. Peripheral Neuropathy under Oncologic Therapies: A Literature Review on Pathogenetic Mechanisms. Int. J. Mol. Sci. 2021, 22, 1980. https://doi.org/10.3390/ ijms22041980

Academic Editor: Nobuaki Egashira Received: 30 November 2020 Accepted: 7 February 2021

Published: 17 February 2021

Publisher's Note: MDPI stays neutral with regard to jurisdictional claims in published maps and institutional affiliations.

Copyright: (c) 2021 by the authors. Licensee MDPI, Basel, Switzerland. This article is an open access article distributed under the terms and conditions of the Creative Commons Attribution (CC BY) license (https:// creativecommons.org/licenses/by/ $4.0 /)$.

\begin{abstract}
Peripheral neurologic complications are frequent adverse events during oncologic treatments and often lead to dose reduction, administration delays with time elongation of the therapeutic plan and, not least, worsening of patients' quality of life. Experience skills are required to recognize symptoms and clinical evidences and the collaboration between different health professionals, in particular oncologists and hospital pharmacists, grants a correct management of this undesirable occurrence. Some classes of drugs (platinates, vinca alkaloids, taxanes) typically develop this kind of side effect, but the genesis of chemotherapy-induced peripheral neuropathy is not linked to a single mechanism. This paper aims from one side at summarizing and explaining all the scattering mechanisms of chemotherapy-induced peripheral neuropathy through a detailed literature revision, on the other side at finding new approaches to possible treatments, in order to facilitate the collaboration between oncologists, hematologists and hospital pharmacists.
\end{abstract}

Keywords: neurotoxicity; anti-cancer drugs; pharmacology; chemotherapy-induced peripheral neuropathy; neurodegeneration; mechanism

\section{Introduction}

Peripheral Nervous System is the trait d'union between brain and spinal cord (Central Nervous System) and the rest of the body, granting the passage and transmission of information to transform in actions. Back to CNS, peripheral nerves send sensory information deriving from the external world.

Peripheral neuropathy $(\mathrm{PN})$ is a more or less serious damage to the peripheral nerves (sensory, motor and autonomic nerves), affecting the $\mathrm{A} \beta$ (myelinated fibers involved in touch and vibration sense), A $\delta$ (thinly myelinated fibers involved in cold perception and thermal pain), and C-fiber (unmyelinated fibers involved in warm temperature perception and thermal pain) functions [1]. It is often accompanied by weakness, numbness and pain, frequently in hands and feet, described by patients as stabbing, burning or tingling, often spreading upward to arms and legs [2]. Other symptoms of PN are extreme sensitivity to touch, pain during normal activities [3], lack of coordination and falling, muscle weakness, paralysis if motor nerves are affected $[4,5]$, while heat intolerance, excessive or lack of sweating, bowel, bladder or digestive problems, changes in blood pressure [6], dizziness or lightheadedness if autonomic nerves are bit [7]. PN can affect a single nerve (mononeuropathy), two or more nerves in different areas (multiple mononeuropathy) or many nerves (polyneuropathy) [8]. 
Exposure to toxins is one of the principal causes of PN. In particular, for some classes of anticancer drugs, PN represents the most frequent cause of therapy interruption, dose reduction, delay and variation of the standard timing of administration, till leading to not optimal clinical outcomes.

The global (acute and chronic) prevalence of Chemotherapy-Induced PN (CIPN), in all its clinical manifestations (sensorial, motor and autonomic) is agent-dependent and, according to 2014 data deriving from a systematic review and meta-analysis by Seretny [9], varies from $68.1 \%$ in the first month after chemotherapy to $60 \%$ at three months and $30 \%$ at six months and more. The highest values have been recorded for platinum-based drugs $(70-100 \%)[5,10]$, taxanes (up to $76 \%)$ [11], thalidomide and its analogues $(20-60 \%)[12,13]$ and ixabepilone (66\%) [14]. More specifically, Sisignano asserted that the neuropathic pain related to chemotherapy treatments affected up to $80 \%$ of patients [15]. These data are expression of a huge clinical impact of CIPN on oncologic patients and have grown up in a few years.

Sensorial and motor alterations represent the most frequent forms of CIPN symptoms and are associated to most drugs (taxanes, platinum salts), involving both large and small fibers, while autonomic manifestations are less frequent and are related predominantly to vinka alkaloyds (small fibers damage) [16-18].

Platinum-based antineoplastic drugs (oxaliplatin and cisplatin), taxanes (paclitaxel, docetaxel), epothilones (ixabepilone), immunomodulatory drugs (thalidomide), vinca alkaloids (vincristine and vinblastine), proteasome inhibitors (bortezomib) and tyrosine kinase inhibitors (sorafenib) are, in approximately decreasing neurotoxic impact order, the classes of antineoplastics that more frequently are associated to CIPN development [19]. Nevertheless, also innovative therapeutic approaches, such as Chimeric Antigen Receptor-T (car-T) cell therapy, in particular tisagenlecleucel used for the treatment of relapsed/refractory diffuse large B-cell lymphoma, has demonstrated to induce a certain grading of neurological toxicity [20].

Different risk factors must be considered to forecast or prevent the neuropathic side effects associated to the chosen anticancer therapy: smoking, advanced age, increased body mass index, uncontrolled diabetes, alcohol abuse vitamin $B$ deficiencies, pre-existing infections (Lyme disease, shingles, Epstein-Barr virus, hepatitis B/C, HIV), autoimmune diseases, (rheumatoid arthritis, lupus), kidney, liver or thyroid disorders, family history of neuropathy $[8,9,21-23]$. Cold allodynia and cold hyperalgesia during chemotherapy has also been identified as a risk factor for persistent CIPN symptoms [9]. Also single nucleotide polymorphisms (SNPs) [8], evidenced during genome-wide association studies (GWAS) have demonstrated to bring a higher risk of CIPN, in particular referring to voltage-gated sodium channels, Schwann cell function-related proteins, receptors for cell surface collagen, receptors involved in neuronal apoptosis, neuronal crest cell development and even an enzyme involved in pyruvate metabolism [9].

Severity of CIPN symptoms varies also as a function of the drug administered and its schedule of treatment and cumulative dose [19], i.e., platinum salts, specifically oxaliplatin, induce immediate acute severe sensory disturbances, while the most frequent taxaneinduced neurotoxicity (paclitaxel more than docetaxel) generates longlasting but less severe symptoms $[24,25]$. No standard management of symptoms is recognized at the moment, though a single pharmacological treatment has been postulated for all CIPN, by oxaliplatin, cisplatin, vincristine and paclitaxel, because of similar overlapping mechanisms of mitotoxicity [26,27], involving the inhibition of TRPV1 [28] or NMDAR [29] activation with additional anti-inflammatory properties, perhaps by inhibiting p38-MAPK [30].

This review aims at summarizing and explaining all the scattering mechanisms of CIPN onset through a detailed literature revision. The knowledge of toxicity profiles and the pathogenetic mechanisms of CIPN onset of old and new drugs in a multidisciplinary dialogue represents a due for all professionals during patients' care path. Experience skills are required to recognize symptoms and clinical evidences and the collaboration between different health professionals, in particular oncologists and hospital pharmacists, grants a correct management of this undesirable occurrence. This research has been the starting 
point for deepening our knowledge on the topic as professionals within a cancer institute and beginning a constant collaboration for the success of the therapies.

\section{Materials and Methods}

A systematic literature research about chemotherapy-induced peripheral neuropathy has been collected with special referring to the reviews on this topic. The keywords used during research were peripheral neuropathy, neurotoxicity, mechanism of neuropathy onset, neuropathic pain associated to taxanes, platinum salts, vinca alkaloyds, bortezomib and TKIs. During the data collecting, Thalidomide's and Ephotilones'data have been found interesting and also inserted in the manuscript, to shed light on all possible mechanisms of CIPN onset.

\section{Results}

Our research has covered a period of about ten years, since 2010 and all the publications have been chosen in order to gain completeness of information on mechanisms of onset, clinical data (prevalence, data emerging from clinical trials), possible prevention or treatment with or without therapeutic agents, genetic studies about the possible risk factors predisposing to CIPN. The information about thalidomide in monotherapy are older than the others, involving papers published before 2010, nevertheless more recent reports have been inserted about the combination therapy of thalidomide and bortezomib in multiple myeloma. Within our hospital and our daily activity, this research has brought us to give to oncologists and hematologists a sort of booklet to help them to prescribe the right drug, timing of administration and dosage, based on the patient's pre-existing comorbidities. On the other hand, hospital pharmacists could enrich their counseling towards patients reporting neuropathic symptoms, suggesting possible alternative remedies or sharing with the physician a possible chrono-modulation of the drug administration.

\section{Discussion}

The study has been conceived as a summit of the knowledge about CIPN induced by the most common neurotoxic anticancer drugs, in order to give them a more right clinical collocation in therapeutic schedules of oncologic patients, which often are affected by different comorbidities susceptible to alter or modify clinical outcomes in terms of toxicity, delay or suspension of their treatments. With respect to already published papers on this topic, our study combines more aspects of this important problematic for the patients and the physicians facing neuropathic symptoms: mechanisms of onset, risk factors, pharmacologic or not pharmacologic treatments, studies upon genetic patterns, possible variation in dose and timing of administration. This is a review of literature, but it has given us the possibility to start collecting a growing casuistry, among all patients in our cancer institute. In the following part of the discussion, we report the principal pharmacological and toxicological characteristics of PN-induced anticancer drugs, summarized in Table 1. 
Table 1. Principal anticancer drugs inducing PN with their pathologic and pharmacologic characteristics.

\begin{tabular}{|c|c|c|c|c|c|c|}
\hline Class of Drugs & Mechanism of Action & Application in Oncology & Mechanism CIPN Onset & Prevalence of CIPN & Risk Factors & References \\
\hline $\begin{array}{l}\text { Taxanes (paclitaxel } \\
\text { docetaxel) }\end{array}$ & $\begin{array}{l}\text { Antimitotic effect due to } \\
\text { tubulin binding } \\
\text { (microtubule stabilizer) }\end{array}$ & $\begin{array}{c}\text { breast, ovarian, uterus, } \\
\text { gastric cancers, NSCLC, } \\
\text { sarcomas, }\end{array}$ & $\begin{array}{l}\text { Microtubule impairment, } \\
\text { loss of axon transport } \\
\text { function, neuroimmunity, } \\
\text { inflammation } \\
\text { (NO,IL-1,TNFa,COX2), ROS } \\
\text { production, ion channel } \\
\text { remodeling, Ca++ signaling, } \\
\text { mitochondrial dysfunction }\end{array}$ & chronic sensorial & $\begin{array}{l}\text { Genetic predisposition, } \\
\text { advanced age, smoke, } \\
\text { pre-existing neuropathy } \\
\text { diabete, autoimmunity }\end{array}$ & {$[16,22,24,25,31-59]$} \\
\hline $\begin{array}{l}\text { Platinum salts (oxaliplatin } \\
\text { and cisplatin) }\end{array}$ & $\begin{array}{l}\text { Antimitotic effect due to } \\
\text { alkylation of DNA N7 } \\
\text { Guanine }\end{array}$ & $\begin{array}{l}\text { colon, pancreas, gastric, } \\
\text { pulmonary, ovarian, }\end{array}$ & $\begin{array}{c}\text { neuroimmunity, } \\
\text { inflammation (NO, IL-1, } \\
\text { TNFa, COX2), ROS } \\
\text { production, ion channel } \\
\text { remodeling, Ca++ signaling, } \\
\text { mitochondrial dysfunction, } \\
\text { protease activation, altered } \\
\text { brain endothelial cells }\end{array}$ & $\begin{array}{l}\text { Acute/chronic motor, } \\
\text { sensorial }\end{array}$ & $\begin{array}{c}\text { Genetic alterations on } \\
\text { GSTP1, GSTM1, } \\
\text { glutathione-S- transferase, } \\
\text { Na+voltage channels, } \\
\text { pre-existing neuropathy }\end{array}$ & {$[41,43,51,58,60-99]$} \\
\hline Bortezomib & Proteasome 26S inhibitor & $\begin{array}{l}\text { multiple myeloma, } \\
\text { lymphomas }\end{array}$ & $\begin{array}{c}\text { Increased sphingolipid } \\
\text { metabolism in astrocytes, } \\
\text { inflammation (TNFa, IL-1), } \\
\text { mitochondrial damage, ROS } \\
\text { production, alteration in } \\
\text { Ca++ signaling }\end{array}$ & Chronic sensorial & $\begin{array}{c}\text { SPT, PKNOX1 and CBS } \\
\text { gene alterations, low levels } \\
\text { of vitamin D, inhibition of } \\
\text { NFkB }\end{array}$ & {$[41,100-116]$} \\
\hline Thalidomide & Immunomodulator effect & multiple myeloma, & ROS production & $\begin{array}{l}\text { Acute/chronic; motor } \\
\text { and autonomic }\end{array}$ & $\begin{array}{l}\text { Advanced age, pre-existing } \\
\text { neuropathy, ADME gene } \\
\text { group alteration, SNPs }\end{array}$ & {$[100,104,114-121]$} \\
\hline $\begin{array}{l}\text { Epothilones } \\
\text { (ixabepilone) }\end{array}$ & $\begin{array}{l}\text { Antimitotic effect due to } \\
\text { tubulin binding } \\
\text { (microtubule stabilizer) }\end{array}$ & breast cancer & See Taxanes & Acute sensorial & See Taxanes & {$[14,122,123]$} \\
\hline $\begin{array}{c}\text { Vinca Alkaloyds } \\
\text { (vincristine, vinorelbine, } \\
\text { vinblastine) }\end{array}$ & $\begin{array}{l}\text { Antimitotic effect due to } \\
\text { tubulin binding (preventing } \\
\text { microtubule } \\
\text { polymerization) }\end{array}$ & lymphomas, breast cancer & $\begin{array}{l}\text { Microtubule impairment, } \\
\text { loss of axon transport } \\
\text { function, altered } \\
\text { ion channels, } \\
\text { neuroinflammation }\end{array}$ & $\begin{array}{c}\text { Acute sensorial motor and } \\
\text { autonomic }\end{array}$ & $\begin{array}{l}\text { ERG2 gene mutation, } \\
\text { polymorphism in CEP72 } \\
\text { gene, diabete, smoke, } \\
\text { decreased serum level of } \\
\text { folic acid and vitamin B12, } \\
\text { pre-existing neuropathy, } \\
\text { low creatinne clearance }\end{array}$ & {$[41,42,111,124-130]$} \\
\hline TKIs (Sorafenib) & $\begin{array}{c}\text { Kinase inhibitor } \\
\text { (proliferation and } \\
\text { angiogenesis inhibition) }\end{array}$ & liver and kidney cancers & $\begin{array}{l}\text { VEGFR inhibition, } \\
\text { expression of Bcl2 }\end{array}$ & Acute & n.a. & [131-133] \\
\hline
\end{tabular}




\subsection{Taxanes}

Chemotherapy based on taxane drugs (paclitaxel, docetaxel, cabazitaxel) is largely prescribed, often with curative intent, in breast, ovarian, lung and prostate cancer [31]. Taxane neuropathy affects $80 \%$ to $97 \%$ of patients and among then, $27 \%$ complaints neuropathic pain [32,33]. A retrospective study [134] indicates that about $10 \%$ of patients under taxane treatment, undergo a dose reduction or delays in administration timing because of TIPN (taxane-induced peripheral neuropathy) symptoms. Other studies have estimated that $25 \%$ to $60 \%$ of all patients will experience lasting neuropathic symptoms months to years after the completion of chemotherapy $[34,35]$ associated with anxiety, sleep disorders and depression [135].

Taxanes' pharmacodynamics involves microtubule-stabilizing mechanisms, prevent thanks to their high affinity with the interior portion of the b-tubulin subunit that block mitosis and tumour cell proliferation. Different timing and schedules of treatment are known and are applicable to different patient's performance status and hematologic pattern, besides referring to neoadjuvant/adjuvant strategy or metastatic disease. Paclitaxel is more neurotoxic than docetaxel and its newer formulation, albumin-bound paclitaxel (Nab-paclitaxel), cannot succed in reducing CIPN incidence though it has reduced overall toxicity [36]. TIPN is usually a sensory dominant neuropathy, mostly affecting small diameter fibers, while motor and autonomic involvement is less frequent $[37,38]$.

Tingling, itching, burning, spontaneous pain, heightened sensitivity to touch (positive sensory symptoms) or loss of touch and pain and loss of hot/cold sensations (negative sensory symptoms) can be both experienced in the extremities (hands and feet) and generally worsen with increasing dose and treatment duration [32].In some patients, symptoms continue up to 1-3 years after therapy and sometimes are lifelong lasting [39].

The negative sensory profile is subsequent to the loss of intraepidermal nerve fiber density and demyelination [40-42,136], besides a degeneration of distal nerve segments (Wallerian degeneration) and an axonal membrane remodelling [137]. Animal models consented to prove this effect, evidencing a decreased number of intraepidermal fibers in rodents and impaired corneal innervation in rats $[43,138]$.

The positive sensory profile is associated to an increased number of ion channels, altered or impaired $\mathrm{Ca}^{2+}$ signalling, neuroinflammation and activation of adjacent silent nociceptors.

Within TIPN positive sensory symptom profile, neuropathic pain includes sensations of stabbing, burning, shooting, tingling, allodynia and hyperalgesia which are maintained by peripheral and central sensitization $[26,139]$. As taxanes are not able to cross the bloodbrain barrier, in the first phases of pain, peripheral nociceptive inputs involve spinal cord and central nervous system; when taxanes start mitochondrial damage, abnormal spontaneous discharge of $\mathrm{A} \delta$ and $\mathrm{C}$-fibers with mechano and thermal hypersensitivity via TRPA1 (mechano and cold sensitivity) and TRPV1 (heat hyperalgesia) receptors at the distal terminal sensory ending takes place [37], leading to a constant dorsal horn excitability (glia cell activation, microglia and astrocytes) [44], which seem to be central in maintaining neuropathic pain, increasing proinflammatory cytokines and brain-derived neurotrophic factor (BDNF) [45]. All these events result in cortical changes and central sensitization [140]. The inhibition of macrophages and microglia prevents the development of mechanical hyperalgesia and epidermal nerve fiber loss [44,46].

TIPN has surely different onset causes, whose role is differently weighted in different patients and clinical conditions. Microtubule impairment, neuroimmune and inflammatory changes, ion channel remodelling, impaired mitochondrial function and genetic predisposition are most of the likely involved mechanisms, also studied through animal and human research models.

Referring to taxane anticancer mechanisms of action, healthy peripheral nerves undergo a similar attack which compromises the dynamic stability of microtubules, a fundamental property for the anterograde transport of nutrients, neurotransmitters and mitochondria from nervous soma to axon extremities and for retrograde transport of used/empty synaptic vesicles and proteins from axons to soma. TIPN is associated to the loss of micro- 
tubule dynamic stability which leads to a loss of transport functions and translates into altered growth cone and filipodia at the sensory endings.

These alterations bring to changes in the morphology and physiology of the peripheral nerves which result in a symmetrical development in a stocking/glove distribution [9]. Longer nerves seem to be more vulnerable to impaired transport, in fact, distal axonopathy and coasting phenomenon are more frequent. The term coasting describes progressive worsening of TIPN symptoms, related to the time for anterograde transport to move the drug from the dorsal root ganglion (DRG) to the distal axon [32].

Gornstein and Swartz $[16,24]$ suggest that transport block may not be the primary cause of paclitaxel-induced PN, based on the evidence that drug inclusion both in the middle and the distal axon in adult mouse DRG neurons scattered a higher sensitivity for the distal portion, while for the middle one no difference was evidenced with respect to control. The results of this study suggest that paclitaxel disrupts growth cone dynamics in filipodial extension of pioneer microtubules in the sensory nerve, leading to their stabilization and impairment at the distal axon. In normal conditions, pioneer microtubules are always in a high metabolic state, granting retraction and advancement of the nerve as the epithelium regenerates [27].

Other studies have suggested that primary mechanisms of TIPN are due to a second low-affinity binding site of taxanes at the end of the microtubules, whose activation scatters the release of mediators of inflammation (IL, NO, and COX-2) [47]. In particular, paclitaxel increases the production/release of pro-inflammatory cytokines (TNF alfa and IL-1 beta) and decreases anti-inflammatory cytokines (IL-4 and IL-10) [141,142]. As a consequence, immune cells activation and neuroinflammation take place [8].

This process includes mitotoxicity, in particular referring to the presence of swollen and vacuolated mitochondria in $\mathrm{A} \delta$ and $\mathrm{C}$ fibers which stimulates $\mathrm{Ca}^{2+}$ release, opening mitochondrial permeability transition pore (mPTP) and leading to mitochondria depolarization $[48,143]$ and neuronal excitability [144]. This damage of axon functions induces a reactive oxidative stress, ion channel changes (TRPV1 via PKC or MAPK), release of inflammatory cytokines and activation of caspase $3 / 7$ [18,19,43].

Damaged mitochondria start an oxidative stress with the production of reactive oxygen species (ROS), both in sensory neurons and the spinal cord [49,50,141,142], which activate apoptotic processes and promote the disruption of cell structure (and consequently demyelination), by a self-amplifying mechanism with further mitochondrial damage. Different studies demonstrated paclitaxel-induced swelling, vacuolation and loss of structure of mitochondria [37,51,52].

As for ion channel alterations, different models have evidenced a decreased expression of $\mathrm{K}^{+}$channels which causes the spontaneous activity of nociceptors and the activation of cation channels TRPV1 and TRPA1, mediators of pain signalling, in DRG neurons [52-54]. To support these observations, antagonists of TRPA1 have demonstrated to reduce inflammation, cold allodynia and hyperalgesia $[55,56,145]$.

In summary, TIPN is mediated by different drug-related effects:

- mitochondrial dysfunction

- axon degeneration

- altered Calcium homeostasis

- changes in peripheral nerve excitability

- immune processes and neuroinflammation

Nerve conduction studies, which measure amplitude and velocity of large myelinated fibers, are not sufficient to monitor changes in sensory neuropathies $[23,146]$, in fact, the early stages of the axonopathy and the worsening clinical conditions over time can be better highlighted through a skin biopsy, quantification of intraepidermal nerve fiber density (IENFD) and quantitative sensory testing (QST). In particular, presence of symptoms with abnormal QST and a normal nerve conduction study are generally sufficient to recognize the diagnosis of small-fiber neuropathy [23]. 215]Antioxidants, vitamins A, B, and E, herbal medicines such as Goshajinkigan, acetyl-1-carnitine, $\mathrm{Ca}^{2+}-\mathrm{Mg}^{2+}$ infusions, acupuncture, 
have been tested for the treatment of TIPN [15,147], but they failed to produce either neuroprotection or alleviation of symptoms [57,148]. Krukowski [148] showed that IL-10 can attenuate paclitaxel-induced CIPN. Practice guidelines from the American Society for Clinical Oncology in 2014 and a consensus statement from the Canadian Pain Society have suggested moderate treatment support with duloxetine, a serotonin-norepinephrine reuptake inhibitor [149-151] in association to physical therapy programs and psychological treatment [152], while no kind of prevention is recognized.

Topical drugs have been also tested to treat TIPN sensory symptoms, with contrastant results from clinical trials:

(a) topical ketamine and amitriptyline demonstrated no improvement in pain scores [153];

(b) topical combination of ketamine, amitriptyline and baclofen demonstrated improved tingling sensory subscales, but no improvement in numbness, thermal pain or functional abilities [154];

(c) topical menthol has been suggested but requires further study [155].

The reason why no ancillary treatment is still recognized lies on the general consideration that targeting the pathway to prevent or minimize TIPN can also affect taxane drug efficacy.

A possible neuroprotective role of physical exercise in TIPN has been reported. A risk analysis reported by Mustafa [156] in breast cancer patients has revealed a 12\% lower risk of peripheral neuropathy for women who regularly made physical exercising of at least $30 \mathrm{~min}$. Identifying specific protocols of physical exercise intensity, frequency, duration and type is one of the best routes for prevention and treatment of TIPN and neuropathic pain, above all for patients' compliance.

\subsection{Platinum Salts}

Cisplatin, carboplatin and oxaliplatin are among the most prescribed chemotherapic drugs for the treatment both of solid and hematologic tumors; in particular, cisplatin and carboplatin are used for small-cell/no-small cell lung, testicular, ovarian, uterine and bladder cancers, but also in refractory lymphoma in DHAP schedule, while oxaliplatin in digestive tract tumors, such as colorectal, oesophagal, stomach, liver, pancreatic cancers and in refractory lymphoma in DHAOX schedule. Cisplatin-induced peripheral neuropathy (CisIPN) is time-, dose and patient-dependent with symptoms appearing after the first dose or after 12 cycles of therapy $[60,157]$, independently from pretreatment, age, sex, tumor type and cotreatment with other chemotherapeutics [61,157]. It is generally recognized that more severe forms of CisIPN appear after cumulative doses above $350 \mathrm{mg} / \mathrm{m}^{2}$ with the most frequency in $92 \%$ of patients at a cumulative dose of $500-600 \mathrm{mg} / \mathrm{m}^{2}$ [62]; a form of chronic CisIPN has been also observed in $5-20 \%$ of patients at 12 months after therapy $[63,157]$. Carboplatin develops a less severe neuropathy observed in 13-42\% of the treated patients [158], while oxaliplatin induces an acute and transient OIPN (oxaliplatin-induced peripheral neuropathy) in $65-98 \%$ of patients in the following hours after each infusion at a dose range from 85 to $130 \mathrm{mg} / \mathrm{m}^{2}$ and lasting up to 5-7 days, with a longer persistence of symptoms in patients receiving 12 cycles of chemotherapy $[64,65]$. Acute OIPN presents with cold-related paresthesias of the extremities (hands and feet), pharyngolaryngeal dysesthesias, jaw spasms, fasciculations and muscle cramps [159]. Cold-induced neuropathy represents the most important difference between oxaliplatin and cisplatin-induced neuropathy [66] and its severity in the first phases of exposition has been associated to the chronic form of OIPN experienced one year later [67], observed in 50-70\% of patients, depending on the intensity of symptoms assessed in its acute clinical presentation [68-70]. A systematic review by Beijers et al. [71], in addition to the study by Briani et al. has reported that OIPN may be present in $26-46 \%$ of patients at the 12-month follow-up, in $24 \%$ of patients at the 15-18-month follow-up and even in $84 \%$ of patients at the 24-month follow-up [71-73]. 
Chronic OIPN occurs in 10\% of patients who received cumulated doses from 510 to $765 \mathrm{mg} / \mathrm{m}^{2}$, increasing to almost $50 \%$ of patients for more than $1000 \mathrm{mg} / \mathrm{m}^{2}$ doses $[74,75]$ and specifically a more severe acute form results in a higher incidence of chronic neuropathy [75].

Gene alterations, such as GSTP1 and GSTM1, glutathione-S-transferase genes and voltage-gated sodium channel genes SCN4A, SCN9A and SCN10A, together with preexisting peripheral neuropathy [75-78] have been demonstrated to be the principal risk factors for OIPN onset.

As for pathogenetic mechanisms for CIPN, like taxanes, platinum salts induce the activation of glial cells, which on turn provoke the activation of immune cells and the release of pro-inflammatory cytokines (interleukins and chemokines), leading to the nociceptor sensitization and hyperexcitability of peripheral neurons, together with blood-brain barrier damage, also mediated byROS, till the development of neuroinflammation. Platinum salts also start a mitochondrial damage with the disruption of the respiratory chain function and an increased production of ROS.

In detail, oxaliplatin and cisplatin form abnormal adducts binding to mitochondrial DNA (mDNA) both in neuronal and non-neuronal cells, which cannot be repaired as mitochondria have no DNA repair system. They start transcription of mDNA, leading to abnormal proteins, impairment of the respiratory chain in mitochondria [79-82,160,161], an increased production of ROS (superoxide anion in particular) and oxidative stress [58,83, $84,162]$, lipid peroxidation, protein and DNA oxidation in both sciatic nerves and the spinal cord. ROS can also accompany a dysregulation of calcium homeostasis and signalling pathways, inducing apoptotic changes in peripheral nerves and in DRG cells. An increase of intracellular $\mathrm{Ca}^{2+}$ concentration may result in calpain (a potent protease) activation, which leads to unregulated proteolysis, directly triggering axon degeneration [163]. Moreover, oxalate deriving from oxaliplatin hydrolysis is a $\mathrm{Ca}^{2+}$ chelator and may lead to an increase in $\mathrm{Na}+$ conductance. Calcium homeostasis alterations also modify the function of protein kinase families (MAPK, mitogen-activated protein kinases; JNK, c-Jun N-terminal kinase; PKC, protein kinase C; AKT, serine-threonine kinases). Platinum-based drugs also modify $\mathrm{Na}^{+}, \mathrm{K}^{+}$and TRP ion channel activity, inducing the hyperexcitability of peripheral neurons and axonal degeneration $[85,86]$.

These toxic effects are part of the mechanisms of action of platinum drugs as anticancer drugs, so that are almost inevitable [87,88].

In the case of oxaliplatin, animal models also demonstrated that the rapid nonenzymatic detachment of the leaving-group oxalate, leading to reactive platinum complexes, has an important role in neuropathy onset, contributing to the characteristic acute cold-induced neuropathy [88]. The results of Fujita et al. also indicate that cells overexpressing Octn1 and Mate1, the recognized oxaliplatin transporters, bring to platinum accumulation in DRG neurons, followed by OIPN. The accumulation of platinum is proportionally correlated with the severity of neuropathy in laboratory animals [89].

IL-1b, IL-6 and TNF-a levels, produced by activated glial cells are able to start neuropathic pain [90,164-166] thanks to platinum salts' ability to activate the Toll-like receptor (TLR) family, especially TLR4. In knockout mice lacking that receptor, pain induced by cisplatin was decreased [91]. Jin's study confirmed that pro-inflammatory cytokines sensitize nociceptors by the modulation of ion channel propertie [167]. Moreover, these cytokines can arrive also to spinal and supraspinal levels [92] chemokine ligands are responsible for the migration and infiltration of monocytes/macrophages and other immune cells, thus contributing to neuroinflammation and pain behaviour in animal models. Other studies have confirmed the role of chemokine CXCL12 [93] and chemokine CX3CL1 signalling in OIPN [94].

Recently, a new neuropsychological syndrome/cognitive impairment has been associated to cancer treatment with platinum salts [95,168-171]. Oxaliplatin theoretically does not pass through blood-brain barrier (BBB), but damage may be caused by proinflammatory cytokines, ROS or other neurotransmitters [172,173]. Branca et al. [96]. demonstrated that oxaliplatin administration in vitro significantly altered junctional and cytoskeletal 
apparatus of endothelial cells, leading to a higher drug concentration in the brain, which probably contribute to pain chronification. The study of Sanna et al. shows that oxaliplatin administration induces changes in the levels of proteins in spinal and supraspinal levels in laboratory animals and suggests a direct correlation between structural changes in the central nervous system and chemotherapy-induced neurotoxicity [97].

A systematic review by Hou describes 26 different treatment options for cisplatininduced IPN, including pharmacological, light, scrambler, magnetic field, acupuncture, dietary and long-wave diathermy therapy [174]. However, duloxetine is the only one drug recommended by the American Society of Clinical Oncology, while photobiomodulation or low-level laser therapy is only occasionally prescribed for treatment of CIPN. Apart these options, a lengthy list of other treatments showed no appreciable value to CIPN sufferers (topical $4 \%$ ketamine and $2 \%$ amitriptyline, tricyclic antidepressants, andamitriptyline, and nortriptyline) [174], besides many antioxidants, such as vitamin B6, vitamin E, omega-3 fatty acids, glutamine, glutathione, acetyl-L-carnitine and $\alpha$-lipoic acid [175,176].

Amifostine was also tested for prevention of CIPN, because one of its active metabolites, WR1065, has been demonstrated to protect differentiated neurons from cisplatininduced damage [98]. This thiol accumulates in normal tissues more than in tumors, protecting them from side effects of radiation and chemotherapy without decreasing their therapeutic efficacy [177].

Finally, among novel treatments for CIPN, manganese chelates are noted to be mimetics for mitochondrial manganese superoxide dismutase and efficient in ROS reduction $[99,178]$.should discuss the results and how they can be interpreted in perspective of previous studies and of the working hypotheses. The findings and their implications should be discussed in the broadest context possible. Future research directions may also be highlighted.

\subsection{Bortezomib}

Bortezomib is an N-protected dipeptide containing a boronic acid instead of a carboxylic acid and is an anti-cancer drug for the treatment of multiple myeloma and mantle cell lymphoma as first and further line treatment, often co-administered within a complex medical protocol together with other medications $[100,101]$. Together with carfilzomib, bortezomib is a reversible proteasome inhibitor thank to its boron atom which binds the catalytic site of the $26 \mathrm{~S}$ proteasome $[100,102]$.with high affinity and specificity, blocking the degradation of cellular proteins and ridding cells of abnormal or misfolded proteins.

Both subcutaneous and intravenous injection provide equal drug exposures and generally comparable therapeutic efficacy administration, though in the former peak plasma levels are $\sim 25-50 \mathrm{nM}$ for $1-2 \mathrm{~h}$ and in the latter case peak plasma levels are $\sim 500 \mathrm{nM}$ for only $\sim 5 \mathrm{~min}$, after which the drug rapidly distributes to tissues with a large volume of distribution ( $500 \mathrm{~L})[101,102]$ and an elimination half-life of 9-15 h. In the light of these data, subcutaneous formulation evokes a lower incidence of neuropathy $[103,104]$. Retrospective analyses have been made to deepen in the possible differences in neurotoxicity between the two routes [105-107]: clinical data are not uniform, in some cases [105] no differences have been evidenced, in others $[106,107]$ a high or higher important incidence of PN has been reported for intravenous with respect to subcutaneous route.

Bortezomib-induced PN generally starts early, often within 3-4 cycles of treatment with a peak around cycle 5, followed by a plateau, but also resolves or improves in twothirds to three-quarters of the patients after a median of 2 to 3 months. This trend suggests a neurotoxic dose threshold rather than a cumulative dose effect and a dose adjustment may be necessary with increasing toxicity.

PN frequency is approximately $34 \%$ of treated patients, who develop chronic, distal and symmetrical sensory syndrome with an important neuropathic pain that may last even for years after drug administration [108]. Also a length-dependent, mixed small and large fiber axonal sensory neuropathy can take place and disappear after several weeks after treatment ends. SUMMIT and CREST clinical trials are the most reliable reports on the out- 
come of bortezomib-induced PN on 256 patients. Within the study population, 90 patients experienced treatment-emergent peripheral neuropathy, in particular, 35 experienced either grade 3 or 4 neuropathy and/or neuropathy leading to discontinuation of treatment $(5 \%$, $14 / 256)$, while dose reduction was required in $12 \%$ of patients (31/256). In $7 \%$ of patients $(19 / 256)$, at least one course of bortezomib was omitted because of peripheral neuropathy.

Other mechanisms of neurotoxicity have been proposed to clarify bortezomib-induced $\mathrm{PN}$, one of which regards its ability to increase sphingolipid metabolism within astrocytes with a subsequent increasing levels of ceramide, sphingosine-1 phosphate (S1P) and dihydrosphingosine-1-phosphate (DH-S1P), that have potent inflammatory and nociceptive actions [109]. S1P receptor-1 (S1PR1) signalling pathways contribute to bortezomibinduced neuropathic pain, because when it hooks to free S1P, an increase in the release of presynaptic glutamate at the level of the dorsal horn of the spinal cord takes place, contributing to the development of neuropathic pain [109]. Alterations in sphingolipid metabolism is often associated to neuronal degeneration and pain, for instance, the mutations in serine palmitoyltransferase (SPT) gene that notoriously lead neuropathic pain in humans [179].In the periphery, bortezomib is able to augment tumor necrosis factor $\alpha(\mathrm{TNF}-\alpha)$ and interleukin-1 $\beta$ production, which in turn have an important role in sphingolipid metabolism. Mitochondrial damage also resulted from bortezomib treatment, giving ROS, which in turn, impair mitochondrial function, like the prior discussed taxanes and platinum salts. Thanks to its cytotoxic mechanism of action, bortezomib also activates the mitochondrial-based apoptotic pathway, dysregulates mitochondrial-mediated $\mathrm{Ca}^{++}$homeostasis, provokes chromatolysis of DRG neurons, followed by cytoplasmic accumulation of eosinophilic material, neurofilaments and juxtanuclear electron-dense cytoplasmic deposits [110].

Some SNPs and other clinical conditions have been identified to clarify the severity and the late versus early-onset bortezomib neuropathy, demonstrating the probable role of pre-existing genetic factors [111]:

- a locus in the PKNOX1 gene and one near the CBS gene [112];

- the inhibition of the nuclear transcription factor NFKB, involved in cell survival and proliferation [113];

- low levels of vitamin $\mathrm{D}$, which are prognostic for a more severe neuropathy in myeloma patients [114].

To date, dose reduction and schedule change algorithm with weekly administration rather than 1-4-8-11 days within a cycle, are the only clinical approaches to face bortezomibinduced PN, as neither neuroprotective agents demonstrated their efficacy nor analgesics, tricyclic antidepressants, anticonvulsants or vitamin supplements as symptomatic treatments gave sufficient results.

There are recommendations concerning the use of nutritional supplements, such as pyridostigmine (vitamin B6) and vitamin C that should be omitted in the course of treatment: vitamin B6 can cause additional sensory neuropathy in patients with impaired renal function and in association with a protein-deficient diet, while vitamin $C$ may interfere with bortezomib metabolism and its proteasome activity.

Interestingly, also intravenous immunoglobulin (IVIG) administration has been proposed by a preliminary report on 9 patients as an effective therapy for symptomatic management of bortezomib-induced PN, being evident an improvement of at least 1 grade in all patients.

\subsection{Thalidomide}

Thalidomide is a glutamic acid derivative for the treatment of multiple myeloma [117], thanks to its immunomodulatory activity, which blocks both the production of tumor necrosis factor-alpha (TNF- $\alpha$ ) and the activation of NF-kB (nuclear factor kappaB), resulting in the dysregulation of neurotrophins with their receptors which accelerates neuronal cell death [180]. Thalidomide has also an antiangiogenic activity by the inhibition of basic fibroblast growth factor (b-FGF) and vascular endothelial growth factor (VEGF), causing 
secondary ischemia and hypoxia of nerve fibres and, subsequently, irreversible damage of sensory neurons [181].

When Wani [118] proposed the role of the dihydroxy metabolite of thalidomide in extensive redox-activated DNA cleavage through the formation of ROS as probable guilt for the well-known thalidomide-induced teratogenesis, a series of preclinical and clinical trials have started to study ROS-dependent mechanisms also for the onset of PN, being typical of the most neurotoxic chemotherapeutics.

Thalidomide-induced peripheral neuropathy occurs in $25-75 \%$ of patients, with dosedependent prevalence and severity [182], in particular in advanced-aged patients with pre-existing neuropathy, responsible for a limited treatment duration [119]. More than other drugs, thalidomide also induces motor impairment and gastrointestinal and cardiovascular autonomic manifestations [182]; all these effects lead approximately $15 \%$ of patients to treatment discontinuation [120]. The median time to onset is usually months, but higher doses accelerate the process, especially in patients with relapsed disease, whose incidence doubles after 6 to 12 months of thalidomide exposure. Recovering from this nerve damage is variable, taking 4 to 6 years for only a quarter of patients and up to 3 years for the first signs of improvement.

Some genetic studies have evidenced that ADME gene group (drug Absorption, Distribution, Metabolism and Excretion), cytochromes and genes involved in neural processes and central nervous system development can possible risk factors for the onset and progressingof thalidomide-induced peripheral neuropathy [115], as well as single nucleotide polymorphisms (SNPs) in genes involved in inflammation and repair mechanisms in the peripheral nervous system [121].

The association bortezomib and thalidomide is a common therapeutic strategy in multiple myeloma $[104,114,115]$. Though their common activity in peripheral neuropathy induction, some studies have evidenced that no incremental effects are experienced by patients [116]. Finally, a retrospective study suggested a lower incidence of PN outcomes and superior efficacy with subcutaneous bortezomib combined with thalidomide and dexamethasone (VTD) in MM when compared with intravenous route [115,116,122].

\subsection{Epothilones}

Epothilones, in particular ixabepilone, are tubulin destabilizers like taxanes, binding preferentially to the beta III tubulin isotype. In the United States, FDA approved ixabepilone for the treatment of breast cancer not responding to other available chemotherapies [14,147], while in Europe this class of drugs didn't received any approved clinical application. The prevalence of CIPN for ixabepilone has been estimated approximately $67 \%$, with an incidence of severe CIPN from $1 \%$ in previously untreated patients to $24 \%$ in pretreated patients [14]. The clinical manifestation of CIPN is similar to taxane, sharing similar mechanism of action both in anticancer and in neuronal damage activity [14]: in particular mild to moderate sensory dominant neuropathy, mostly affecting small-diameter sensory fibers, in form of paresthesias, numbness and pain in the feet and hands (stocking-andglove distribution), while motor involvement is rare, manifesting as mild muscle weakness and autonomic manifestation was observed in less than $1 \%$ of patients. These symptoms are dose-dependent and are reversible with treatment discontinuation [14]. Intuitively, the pathomechanisms for PN induced by epothilones are also similar to taxanes:

- microtubule disruption impairs axonal transport and leads to Wallerian degeneration;

- altered activity of ion channels and hyperexcitability of peripheral neurons;

- mitochondrial damage, which increases the production of ROS that insult neuronal enzymes, proteins and lipids as well as provoke apoptotic changes and altered excitability to peripheral nerves [183];-ROS release stimulates the attraction and activation of T-lymphocytes and monocytes, as well as pro-inflammatory cytokines (interleukins and chemokines), which are responsible for neuroinflammation. 
Being epothilone-induced PN severity milder than taxanes [122], it is generally accepted that off-target mechanisms responsible for taxane-induced neuropathy may not be shared for epothilones, but the question is still under investigation.

\subsection{Vinca Alkaloids}

Vincristine, vinblastine, vinorelbine and vindesine are the well-known phase $\mathrm{M}$ cyclespecific drugs belonging to this class of chemotherapeutics, commonly prescribed in the treatment of different tumors, such as Hodgkin and non-Hodgkin lymphoma, testicular cancer and non-small cell lung cancer. In analogy to taxanes, vinca alkaloids bind with tubuline, but blocking its polymerization and assembly into microtubules cell and lead to disrupting axonal transport. Though unable to readily cross the blood-brain barrier, they can act on the soma of peripheral nerves, generating a dose-dependent sensorimotor neuropathy, with symptoms' onset (usually pain in hands and feet) within the first months of treatment. Patients also experienced muscle weakness, including wrist extensors, dorsiflexor weakness and cramping [8].

Vincristine is generally considered the most neurotoxic drug among vinca alkaloids, followed by vinblastine and vinorelbine: its neurotoxic effects involve both sensory (early symptoms at cumulative doses of $4 \mathrm{mg} / \mathrm{m}^{2}$ ) and motor (distal weakness after $6-8 \mathrm{mg} / \mathrm{m}^{2}$ ) and autonomic fibers in up to one-third of patients [123]. Vincristine-induced neuropathic pain is principally due to axonal distal neuropathy by disrupting the microtubular both fast and slow axonal transport system, but also a reduction of sensory nerve action potential amplitude has been reported [124]. Vincristine also induces ultrastructural changes in the cytoskeleton of large myelinated axons and an accumulation of neurofilaments in dorsal sensory ganglion neurons $[125,184]$. Both sensory and motor neuropathy with vinorelbine is usually milder than vincristine and has been reported in $14 \%$ to $48 \%$ of patients receiving a total dose of $30 \mathrm{mg} / \mathrm{m}^{2}$ [126].

The recognized and principal pathogenetic mechanisms of CIPN by vinca alkaloids are:

- changes to large axons and DRG neurons, which leads to Wallerian degeneration;

- altered activity of ion channels and hyperexcitability of peripheral neurons;

- inhibition of polymerization into microtubules inhibits axonal transport, generating distal

- $\quad$ axonopathy and altered excitability;

- attraction and activation of immune cells start the release of pro-inflammatory cytokines (interleukins and chemokines), inducing neuroinflammation.

FDA issued a black box warning on vincristine prescription in Charcot-Marie-Tooth disease (CMT) patients [127], having the ERG2 gene mutation, who have been demonstrated more sensitive to vincristine [59], as well as a polymorphism in the CEP72 gene, which is associated with an increased risk and severity of vincristine-induced neuropathy [128].Due to their hepatic metabolism by CYP3A4 enzymes, a concomitant use of taxanes or CYP3A4 inhibitors (Ketoconazole, clarithromycin, ritonavir) increases the risk of vinca alkaloids-induced neuropathy, together with a decreased serum level of folic acid and vitamin B12, pre-existing neuropathy and comorbidities, such as diabetes, smoking history and low creatinine clearance. There is no specific treatment for vinca alkaloid induced peripheral neuropathy. The use of pyridoxine or pyridostigmine revealed a certain efficacy in vincristine-induced neuropathy [129]. A topical cream containing capsaicin demonstrated to give benefit in PN [130,185], thanks to the depletion of P substance in the distal nerve endings. In the case of paraesthesia and pain, the patient should be treated with carbamazepine, imipramine or lignocaine [186].

\subsection{Tyrosine Kinase Inhibitors: Sorafenib}

A tyrosine kinase inhibitor (TKI) is an anticancer drug able to inhibit tyrosine kinase receptors, which are endowed of an enzymatic activity, responsible for the activation by phosphorylation of many proteins by signal transduction cascades. TKIs operate by different mechanisms: 
- competition withthe physiological ligand adenosine triphosphate(ATP) on the active site within the receptor;

- binding outside the active site (allosteric site) of the enzymatic portion of the receptor, affecting its activity and conformational status [187];

- depriving tyrosine kinases of access to the Cdc37-Hsp90 molecular chaperone system on which they depend for their cellular stability, leading to their ubiquitylation and degradation [188].

With an incidence of $>10 \%$, several oral TKIs can induced PN: brigatinib, crizotinib, encorafenib, imatinib, ivosidenib, ixazomib, lorlatinib, ponatinib, vemurafenib, sorafenib [189-194]. Sorafenib is a TKI anticancer drug approved in clinics for the treatment of hepatocellular and renal carcinomas, whose repeated administration causes the onset of a peripheral painful neuropathy, which often leads to premature discontinuation of therapy, being resistant to common analgesic drugs [131,195]. The pathomechanism for this $\mathrm{PN}$ is still under investigation, but the first studies have identified a direct neurotrophic role for vascular endothelial growth factor (VEGF). VEGFR inhibition by sorafenib seems to be responsible for peripheral sensory neuropathies, interfering with the endogenous neuroprotective action of VEGF on sensory neurons. This role of VEGF/VEGFR interaction provides an unprecedented evidence that VEGF receptor inhibitors may themselves trigger a painful neuropathy and aggravate paclitaxel-induced neuropathies, when used in combination. For the same reason, also the anti-VEGF bevacizumab in association to paclitaxel precipitates taxane-induced PN $[132,196]$. The disruption of the neuroprotective effect of VEGF leads to neuronal stress and apoptosis through a mechanism involving VEGF receptor-2-mediated expression of the anti-apoptotic protein Bcl2 [197]. Due to this peculiar pathogenetic mechanism which is also its biological target as anticancer drug, sorafenib-induced PN can be modulated only with dose reduction and often resolved by treatment discontinuation.

All the described drugs or class of drugs induce CIPN preferentially in patients with comorbilities. Neither drugs in therapy or prevention have succeeded in ameliorating sharply neuropathic symptoms and pain, nor quantitative assessment of neuropathy has been authorized or approved so far. Nevertheless, since taxanes and platinum salts are known to hit first small autonomic C-fibers, some efforts have been made to quantify neuropathic damagein the early steps of the anticancer treatment [133,198-200]. Recently, a sudomotor function testing has been suggested to screen early peripheral neuropathy, on the basis that sweat glands are innervated by small C-fibers,. Other assessment tools have already been reported in literature [198-200]:

- skin biopsy to determine the intradermal nerve fiber density and innervated skin structure;

- corneal confocal microscopy to quantify small nerve fibers in the cornea;

- $\quad$ sympathetic skin response, measured the unmyelinated nerve sudormotor function after a transient change in electrical skin potential;

- axon flare reflex tests, evidencing the hyperemic response of the axons;

- pain-related evoked potentials to assess the nociceptive system.

If the route to quantify neurotoxicity induced by these drugs has recently brought to some results, the treatment of CIPN is still far from a common consensus.

This paper is a starting point for opening in our hospital a new scenario for the preventive evaluation of neuropathic onset and has energized our efforts to start creating a database with real data about our patients. In the next future, these data together with clinical outcomes will be object of an original publication.

\section{Conclusions}

Chemotherapy-induced painful neuropathy is a major side effect of several chemotherapeutic agents commonly administered by most patients. To prevent or alleviate its symptoms without limiting the potentially life-saving therapy is a due aim for oncologists, physicians and hospital pharmacists who prescribe and manage anticancer drugs. The negative impact on patients' quality of life constitutes a major problem both for the path 
of cure they are passing through and for their health care providers. For this reason, in high-risk patients, a neurological examination with electrophysiological evaluation should be done early and as soon as first symptoms appear.

Different drugs have been tested to reduce the incidence or severity of CIPN, but none of them are currently applied or strongly recommended. In the ASCO guidelines, no agent for the prevention and only a moderate recommendation for duloxetine in treatment are present.

Understanding CIPN pathomechanisms and risk factors is the only route to identify the most susceptible patients and stimulate research in new possible treatments, together with next advances in genome-wide association studies (GWAS), that could permit the identification of critical genes involved in biological pathways leading to peripheral nerve damage [201]. In the future, a translation of the GWAS results would allow the prediction of CIPN occurrence during chemotherapy administration and could address also to target therapies for managing it.

Author Contributions: Conceptualization, M.L. and C.L., methodology, M.L., software, V.U., validation, P.N. and S.F.; formal analysis, C.C., S.F. and D.T., investigation, M.L., resources, M.L., data curation, C.L., writing — original draft preparation, M.L. and C.L., writing—review and editing, M.L., visualization, D.T. and G.R.; supervision, P.N., D.T. and G.R.; project administration, M.L. and C.L. and G.R., funding acquisition, C.D.G. All authors have read and agreed to the published version of the manuscript.

Funding: This research received no external funding.

Institutional Review Board Statement: Not applicable.

Informed Consent Statement: Not applicable.

Data Availability Statement: Not applicable.

Conflicts of Interest: The authors declare no conflict of interest.

\section{References}

1. Abraira, V.E.; Ginty, D.D. The Sensory Neurons of Touch. Neuron 2013, 79, 618-639. [CrossRef]

2. Bernhardson, B.-M.; Tishelman, C.; Rutqvist, L.E. Chemosensory Changes Experienced by Patients Undergoing Cancer Chemotherapy: A Qualitative Interview Study. J. Pain Symptom Manag. 2007, 34, 403-412. [CrossRef] [PubMed]

3. Jones, D.; Zhao, F.; Brell, J.; Lewis, M.A.; Loprinzi, C.L.; Weiss, M.; Fisch, M.J. Neuropathic symptoms, quality of life, and clinician perception of patient care in medical oncology outpatients with colorectal, breast, lung, and prostate cancer. J. Cancer Surviv. 2014, 9, 1-10. [CrossRef] [PubMed]

4. Kolb, N.A.; Smith, A.G.; Singleton, J.R.; Beck, S.L.; Stoddard, G.J.; Brown, S.; Mooney, K. The Association of ChemotherapyInduced Peripheral Neuropathy Symptoms and the Risk of Falling. JAMA Neurol. 2016, 73, 860-866. [CrossRef] [PubMed]

5. Banach, M.; Juranek, J.K.; Zygulska, A.L. Chemotherapy-induced neuropathies-a growing problem for patients and health care providers. Brain Behav. 2016, 7, e00558. [CrossRef]

6. Adams, S.C.; Schondorf, R.; Benoit, J.; Kilgour, R.D. Impact of cancer and chemotherapy on autonomic nervous system function and cardiovascular reactivity in young adults with cancer: A case-controlled feasibility study. BMC Cancer 2015, 15, 1-13. [CrossRef] [PubMed]

7. Molassiotis, A.; Cheng, H.L.; Lopez, V.; Au, J.S.K.; Chan, A.; Bandla, A.; Leung, A.K.T.; Li, Y.C.; Wong, K.H.; Suen, L.K.P.; et al. Are we mis-estimating chemotherapy-induced peripheral neuropathy? Analysis of assessment methodologies from a prospective, multinational, longitudinal cohort study of patients receiving neurotoxic chemotherapy. BMC Cancer 2019, 19, 1-19. [CrossRef] [PubMed]

8. Zajączkowska, R.; Kocot-Kępska, M.; Leppert, W.; Wrzosek, A.; Mika, J.; Wordliczek, J. Mechanisms of Chemotherapy-Induced Peripheral Neuropathy. Int. J. Mol. Sci. 2019, 20, 1451. [CrossRef] [PubMed]

9. Seretny, M.; Currie, G.L.; Sena, E.S.; Ramnarine, S.; Grant, R.; MacLeod, M.R.; Colvin, L.A.; Fallon, M. Incidence, prevalence, and predictors of chemotherapy-induced peripheral neuropathy: A systematic review and meta-analysis. Pain 2014, 155, 2461-2470. [CrossRef] [PubMed]

10. Mcwhinney, S.R.; Goldberg, R.M.; Mcleod, H.L. Platinum Neurotoxicity Pharmacogenetics. Mol. Cancer. 2009, 8, 10-16. [CrossRef] [PubMed]

11. Park, S.B.; Kwok, J.B.; Loy, C.T.; Friedlander, M.L.; Lin, C.S.; Krishnan, A.V.; Kiernan, M.C. Paclitaxel-Induced Neuropathy: Potential Association of MAPT and GSK3B Genotypes. BMC Cancer 2014, 14, 993. [CrossRef] [PubMed] 
12. Cavaletti, G.; Beronio, A.; Reni, L.; Ghiglione, E.; Schenone, A.; Briani, C.; Carpo, M. Thalidomide Sensory Neurotoxicity: A Clinical and Neurophysiologic Study. Neurology 2004, 62, 2291-2293. [CrossRef] [PubMed]

13. Plasmati, R.; Pastorelli, F.; Cavo, M.; Petracci, E.; Zamagni, E.; Tosi, P.; Tassinari, C.A. Neuropathy in Multiple Myeloma Treated with Thalidomide: A Prospective Study. Neurology 2007, 69, 573-581. [CrossRef] [PubMed]

14. Vahdat, L.T.; Thomas, E.S.; Roche, H.H.; Hortobagyi, G.N.; Sparano, J.A.; Yelle, L.; Perez, E.A. Ixabepilone-Associated Peripheral Neuropathy: Data from Across the Phase II and III Clinical Trials. Supportive Care Cancer 2012, 20, 2661-2668. [CrossRef] [PubMed]

15. Sisignano, M.; Baron, R.; Scholich, K.; Geisslinger, G. Mechanism-based treatment for chemotherapy-induced peripheral neuropathic pain. Nat. Rev. Neurol. 2014, 10, 694-707. [CrossRef] [PubMed]

16. Gornstein, E.L.; Schwarz, T.L. Neurotoxic mechanisms of paclitaxel are local to the distal axon and independent of transport defects. Exp. Neurol. 2017, 288, 153-166. [CrossRef]

17. Han, F.Y.; Smith, M.T. Pathobiology of cancer chemotherapy-induced peripheral neuropathy (CIPN). Front. Pharm. 2013, 4, 156. [CrossRef]

18. Miltenburg, N.; Boogerd, W. Chemotherapy-induced neuropathy: A comprehensive survey. Cancer Treat. Rev. 2014, 40, 872-882. [CrossRef] [PubMed]

19. Cioroiu, C.; Weimer, L.H. Update on Chemotherapy-Induced Peripheral Neuropathy. Curr. Neurol. Neurosci. Rep. 2017, 17, 2461. [CrossRef] [PubMed]

20. Maziarz, R.T.; Schuster, S.J.; Romanov, V.V.; Rusch, E.S.; Li, J.; Signorovitch, J.E.; Maloney, D.G.; Locke, F.L. Grading of neurological toxicity in patients treated with tisagenlecleucel in the JULIET trial. Blood Adv. 2020, 4, 1440-1447. [CrossRef]

21. Candelario, N.; Wongrakpanich, S.; Morginstin, M.S. Predictors of chemotherapy-induced peripheral neuropathy among breast cancer patients treated with taxanes. J. Clin. Oncol. 2015, 33, 90. [CrossRef]

22. Kuş, T.; Aktaş, G.; Kalender, M.E.; Sevinc, A.; Kul, S.; Suner, A.; Ulker, E.; Camci, C. Taxane-induced peripheral sensorial neuropathy in cancer patients is associated with duration of diabetes mellitus: A single-center retrospective study. Support. Care Cancer 2015, 24, 1175-1179. [CrossRef] [PubMed]

23. Hoeijmakers, J.G.; Faber, C.G.; Lauria, G.; Merkies, I.S.J.; Waxman, S.G. Small-fibre neuropathies-advances in diagnosis, pathophysiology and management. Nat. Rev. Neurol. 2012, 8, 369-379. [CrossRef]

24. Gornstein, E.; Schwarz, T.L. The paradox of paclitaxel neurotoxicity: Mechanisms and unanswered questions. Neuropharmacol. 2014, 76, 175-183. [CrossRef] [PubMed]

25. Bennett, G.J.; Liu, G.K.; Xiao, W.H.; Jin, H.W.; Siau, C. Terminal arbor degeneration-A novel lesion produced by the antineoplastic agent paclitaxel. Eur. J. Neurosci. 2011, 33, 1667-1676. [CrossRef] [PubMed]

26. Grisold, W.; Cavaletti, G.; Windebank, A.J. Peripheral neuropathies from chemotherapeutics and targeted agents: Diagnosis, treatment, and prevention. Neuro Oncol. 2012, 14, iv45-iv54. [CrossRef] [PubMed]

27. Starobova, H.; Vetter, I. Pathophysiology of Chemotherapy-Induced Peripheral Neuropathy. Front. Mol. Neurosci. 2017, 10, 174. [CrossRef] [PubMed]

28. Ji, R.R.; Samad, T.A.; Jin, S.X.; Schmoll, R.; Woolf, C.J. P38 MAPK Activation by NGF in Primary Sensory Neurons After In-flammation Increases TRPV1 Levels and Maintains Heat Hyperalgesia. Neuron 2002, 36, 57-68. [CrossRef]

29. Wu, L.-J.; Zhuo, M. Targeting the NMDA receptor subunit NR2B for the treatment of neuropathic pain. Neurotherapy 2009, 6, 693-702. [CrossRef] [PubMed]

30. Li, Y.; Zhang, H.; Kosturakis, A.K.; Cassidy, R.M.; Zhang, H.; Kennamer-Chapman, R.M.; Jawad, A.B.; Colomand, C.M.; Harrison, D.S.; Dougherty, P.M. MAPK signaling downstream to TLR4 contributes to paclitaxel-induced peripheral neuropathy. Brain Behav. Immun. 2015, 49, 255-266. [CrossRef] [PubMed]

31. Tkaczuk, K.H.; A Yared, J. Update on taxane development: New analogs and new formulations. Drug Des. Dev. 2012, 6, 371-384. [CrossRef]

32. Hammond, E.A.; Pitz, M.; Shay, B. Neuropathic Pain in Taxane-Induced Peripheral Neuropathy: Evidence for Exercise in Treatment. Neurorehabilit. Neural Repair 2019, 33, 792-799. [CrossRef]

33. Reyes-Gibby, C.C.; Morrow, P.K.; Buzdar, A.U.; Shete, S. Chemotherapy-Induced Peripheral Neuropathy as a Predictor of Neuropathic Pain in Breast Cancer Patients Previously Treated with Paclitaxel. J. Pain 2009, 10, 1146-1150. [CrossRef] [PubMed]

34. Hershman, D.L.; Weimer, L.H.; Wang, A.; Kranwinkel, G.; Brafman, L.; Fuentes, D.; Awad, D.; Crew, K.D. Association between patient reported outcomes and quantitative sensory tests for measuring long-term neurotoxicity in breast cancer survivors treated with adjuvant paclitaxel chemotherapy. Breast Cancer Res. Treat. 2010, 125, 767-774. [CrossRef] [PubMed]

35. Park, S.B.; Lin, C.S.-Y.; Krishnan, A.V.; Friedlander, M.L.; Lewis, C.R.; Kiernan, M.C. Early, progressive, and sustained dysfunction of sensory axons underlies paclitaxel-induced neuropathy. Muscle Nerve 2010, 43, 367-374. [CrossRef] [PubMed]

36. Peng, L.; Bu, Z.; Ye, X.; Zhou, Y.; Zhao, Q. Incidence and risk of peripheral neuropathy with nab-paclitaxel in patients with cancer: A meta-analysis. Eur. J. Cancer Care 2017, 26, e12407. [CrossRef]

37. Flatters, S.J.L.; Bennett, G.J. Studies of peripheral sensory nerves in paclitaxel-induced painful peripheral neuropathy: Evidence for mitochondrial dysfunction. Pain 2006, 122, 245-257. [CrossRef] [PubMed]

38. De Iuliis, F.; Taglieri, L.; Salerno, G.; Lanza, R.; Scarpa, S. Taxane induced neuropathy in patients affected by breast cancer: Literature review. Crit. Rev. Oncol. 2015, 96, 34-45. [CrossRef] [PubMed]

39. Eckhoff, L.; Knoop, A.; Jensen, M.B.; Ewertz, M. Persistence of docetaxel-induced neuropathy and impact on quality of life among breast cancer survivors. Eur. J. Cancer 2015, 51, 292-300. [CrossRef] 
40. Velasco, R.; Bruna, J. Taxane-Induced Peripheral Neurotoxicity. Toxics 2015, 3, 152-169. [CrossRef] [PubMed]

41. Boehmerle, W.; Huehnchen, P.; Peruzzaro, S.; Balkaya, M.; Endres, M. Electrophysiological, behavioral and histological characterization of paclitaxel, cisplatin, vincristine and bortezomib-induced neuropathy in C57Bl/6 mice. Sci. Rep. 2015, 4, 6370. [CrossRef] [PubMed]

42. Siau, C.; Xiao, W.; Bennett, G.J. Paclitaxel- and vincristine-evoked painful peripheral neuropathies: Loss of epidermal innervation and activation of Langerhans cells. Exp. Neurol. 2006, 201, 507-514. [CrossRef]

43. Xiao, W.H.; Zheng, H.; Bennett, G.J. Characterization of oxaliplatin-induced chronic painful peripheral neuropathy in the rat and comparison with the neuropathy induced by paclitaxel. Neurosci. 2012, 203, 194-206. [CrossRef] [PubMed]

44. Zhang, H.; Li, Y.; De Carvalho-Barbosa, M.; Kavelaars, A.; Heijnen, C.J.; Albrecht, P.J.; Dougherty, P.M. Dorsal Root Ganglion Infiltration by Macrophages Contributes to Paclitaxel Chemotherapy-Induced Peripheral Neuropathy. J. Pain 2016, 17, 775-786. [CrossRef] [PubMed]

45. Ruiz-Medina, J.; Baulies, A.; Bura, S.; Valverde, O. Paclitaxel-induced neuropathic pain is age dependent and devolves on glial response. Eur. J. Pain 2012, 17, 75-85. [CrossRef] [PubMed]

46. Liu, C.-C.; Lu, N.; Cui-Cui, L.; Yang, T.; Zhao, Z.-Q.; Xin, W.-J.; Liu, X.-G.; Cui-Cui, L. Prevention of Paclitaxel-Induced Allodynia by Minocycline: Effect on Loss of Peripheral Nerve Fibers and Infiltration of Macrophages in Rats. Mol. Pain 2010, 6, 76. [CrossRef] [PubMed]

47. Fitzpatrick, F.; Wheeler, R. The immunopharmacology of paclitaxel (Taxol $\left.{ }^{\circledR}\right)$, docetaxel (Taxotere ${ }^{\circledR}$ ), and related agents. Int. Immunopharmacol. 2003, 3, 1699-1714. [CrossRef] [PubMed]

48. Kidd, J.F.; Pilkington, M.F.; Schell, M.J.; Fogarty, K.E.; Skepper, J.N.; Taylor, C.W.; Thorn, P. Paclitaxel Affects Cytosolic Calcium Signals by Opening the Mitochondrial Permeability Transition Pore. J. Biol. Chem. 2002, 277, 6504-6510. [CrossRef] [PubMed]

49. Duggett, N.A.; Griffiths, L.A.; McKenna, O.E.; De Santis, V.; Yongsanguanchai, N.; Mokori, E.B.; Flatters, S.J.L. Oxidative stress in the development, maintenance and resolution of paclitaxel-induced painful neuropathy. Neurosci. 2016, 333, 13-26. [CrossRef] [PubMed]

50. Xiao, W.H.; Zheng, H.; Zheng, F.Y.; Nuydens, R.; Meert, T.F.; Bennett, G.J. Mitochondrial abnormality in sensory, but not motor, axons in paclitaxel-evoked painful peripheral neuropathy in the rat. Neurosci. 2011, 199, 461-469. [CrossRef]

51. Xiao, W.H.; Bennett, G.J. Effects of mitochondrial poisons on the neuropathic pain produced by the chemotherapeutic agents, paclitaxel and oxaliplatin. Pain 2012, 153, 704-709. [CrossRef] [PubMed]

52. Zhang, M.H.; Dougherty, P.M. Enhanced Excitability of Primary Sensory Neurons and Altered Gene Expression of Neuronal Ion Channels in Dorsal Root Ganglion in Paclitaxel-induced Peripheral Neuropathy. Anesth. 2014, 120, 1463-1475. [CrossRef] [PubMed]

53. Hara, T.; Chiba, T.; Abe, K.; Makabe, A.; Ikeno, S.; Kawakami, K.; Utsunomiya, I.; Hama, T.; Taguchi, K. Effect of paclitaxel on transient receptor potential vanilloid 1 in rat dorsal root ganglion. Pain 2013, 154, 882-889. [CrossRef] [PubMed]

54. Materazzi, S.; Fusi, C.; Benemei, S.; Pedretti, P.; Patacchini, R.; Nilius, B.; Prenen, J.; Creminon, C.; Geppetti, P.; Nassini, R. TRPA1 and TRPV4 mediate paclitaxel-induced peripheral neuropathy in mice via a glutathione-sensitive mechanism. Pflügers Arch. Eur. J. Physiol. 2012, 463, 561-569. [CrossRef] [PubMed]

55. Chen, Y.; Yang, C.; Wang, Z. Proteinase-activated receptor 2 sensitizes transient receptor potential vanilloid 1, transient receptor potential vanilloid 4, and transient receptor potential ankyrin 1 in paclitaxel-induced neuropathic pain. Neurosci. 2011, 193, 440-451. [CrossRef] [PubMed]

56. Li, Y.; North, R.Y.; Rhines, L.D.; Tatsui, C.E.; Rao, G.; Edwards, D.D.; Cassidy, R.M.; Harrison, D.S.; Johansson, C.A.; Zhang, H.; et al. DRG Voltage-Gated Sodium Channel 1.7 Is Upregulated in Paclitaxel-Induced Neuropathy in Rats and in Humans with Neuropathic Pain. J. Neurosci. 2018, 38, 1124-1136. [CrossRef]

57. Hershman, D.L.; Unger, J.M.; Crew, K.D.; Minasian, L.M.; Awad, D.; Moinpour, C.M.; Hansen, L.; Lew, D.L.; Greenlee, H.; Fehrenbacher, L.; et al. Randomized Double-Blind Placebo-Controlled Trial of Acetyl-L-Carnitine for the Prevention of TaxaneInduced Neuropathy in Women Undergoing Adjuvant Breast Cancer Therapy. J. Clin. Oncol. 2013, 31, 2627-2633. [CrossRef]

58. Zheng, H.; Xiao, W.H.; Bennett, G.J. Functional deficits in peripheral nerve mitochondria in rats with paclitaxel- and oxaliplatinevoked painful peripheral neuropathy. Exp. Neurol. 2011, 232, 154-161. [CrossRef] [PubMed]

59. Nakamura, T.; Hashiguchi, A.; Suzuki, S.; Uozumi, K.; Tokunaga, S.; Takashima, H. Vincristine exacerbates asymptomatic Charcot-Marie-Tooth disease with a novel EGR2 mutation. Neurogenetics 2012, 13, 77-82. [CrossRef]

60. Van Der Hoop, R.G.; Van Der Burg, M.E.L.; Huinink, W.W.B.T.; Van Houwelingen, J.C.; Neijt, J.P. Incidence of neuropathy in 395 patients with ovarian cancer treated with or without cisplatin. Cancer 1990, 66, 1697-1702. [CrossRef]

61. Schmoll, H.-J.; Kollmannsberger, C.; Metzner, B.; Hartmann, J.T.; Schleucher, N.; Schöffski, P.; Schleicher, J.; Rick, O.; Beyer, J.; Hossfeld, D.; et al. Long-Term Results of First-Line Sequential High-Dose Etoposide, Ifosfamide, and Cisplatin Chemotherapy Plus Autologous Stem Cell Support for Patients with Advanced Metastatic Germ Cell Cancer: An Extended Phase I/II Study of the German Testicular Cancer Study Group. J. Clin. Oncol. 2003, 21, 4083-4091. [CrossRef] [PubMed]

62. Krarup-Hansen, A.; Helweg-Larsen, S.; Schmalbruch, H.; Rorth, M.; Krarup, C. Neuronal involvement in cisplatin neuropathy: Prospective clinical and neurophysiological studies. Brain 2006, 130, 1076-1088. [CrossRef] [PubMed]

63. Mollman, J.E.; Glover, D.J.; Hogan, W.M.; Furman, R.E. Cisplatin Neuropathy. Risk Factors, Prognosis, and Protection by WR-2721. Cancer 1988, 61, 2192-2195. [CrossRef] [PubMed] 
64. Leonard, G.D.; A Wright, M.; Quinn, M.G.; Fioravanti, S.; Harold, N.; Schuler, B.; Thomas, R.R.; Grem, J.L. Survey of oxaliplatinassociated neurotoxicity using an interview-based questionnaire in patients with metastatic colorectal cancer. BMC Cancer $2005,5,116$. [CrossRef] [PubMed]

65. Gebremedhn, E.G.; Shortland, P.J.; Mahns, D.A. The incidence of acute oxaliplatin-induced neuropathy and its impact on treatment in the first cycle: A systematic review. BMC Cancer 2018, 18, 1-10. [CrossRef] [PubMed]

66. Deuis, J.R.; Zimmermann, K.; Romanovsky, A.A.; Possani, L.D.; Cabot, P.J.; Lewis, R.J.; Vetter, I. An animal model of oxaliplatininduced cold allodynia reveals a crucial role for Nav1.6 in peripheral pain pathways. Pain 2013, 154, 1749-1757. [CrossRef]

67. Attal, N.; Bouhassira, D.; Gautron, M.; Vaillant, J.N.; Mitry, E.; Lepère, C.; Rougier, P.; Guirimand, F. Thermal hyperalgesia as a marker of oxaliplatin neurotoxicity: A prospective quantified sensory assessment study. Pain 2009, 144, 245-252. [CrossRef] [PubMed]

68. Storey, D.J.; Sakala, M.; McLean, C.M.; Phillips, H.A.; Dawson, L.K.; Wall, L.R.; Fallon, M.T.; Clive, S. Capecitabine combined with oxaliplatin (CapOx) in clinical practice: How significant is peripheral neuropathy? Ann. Oncol. 2010, 21, 1657-1661. [CrossRef] [PubMed]

69. Tofthagen, C.S.; McAllister, R.D.; McMillan, S.C. Peripheral Neuropathy in Patients With Colorectal Cancer Receiving Oxaliplatin. Clin. J. Oncol. Nurs. 2011, 15, 182-188. [CrossRef]

70. Park, S.B.; Lin, C.S.; Krishnan, A.V.; Goldstein, D.; Friedlander, M.L.; Kiernan, M.C. Long-Term Neuropathy After Oxaliplatin Treatment: Challenging the Dictum of Reversibility. Oncol. 2011, 16, 708-716. [CrossRef] [PubMed]

71. Beijers, A.J.M.; Mols, F.; Vreugdenhil, G. A systematic review on chronic oxaliplatin-induced peripheral neuropathy and the relation with oxaliplatin administration. Support. Care Cancer 2014, 22, 1999-2007. [CrossRef] [PubMed]

72. Selvy, M.; Pereira, B.; Kerckhove, N.; Gonneau, C.; Feydel, G.; Pétorin, C.; Vimal-Baguet, A.; Melnikov, S.; Kullab, S.; Hebbar, M.; et al. Long-Term Prevalence of Sensory Chemotherapy-Induced Peripheral Neuropathy for 5 Years after Adjuvant FOLFOX Chemotherapy to Treat Colorectal Cancer: A Multicenter Cross-Sectional Study. J. Clin. Med. 2020, 9, 2400. [CrossRef] [PubMed]

73. Beijers, A.J.M.; Mols, F.; Tjan-Heijnen, V.C.G.; Faber, C.G.; Van De Poll-Franse, L.V.; Vreugdenhil, G. Peripheral neuropathy in colorectal cancer survivors: The influence of oxaliplatin administration. Results from the population-based PROFILES registry. Acta Oncol. 2015, 54, 463-469. [CrossRef]

74. De Gramont, A.; Figer, A.; Seymour, M.; Homerin, M.; Hmissi, A.; Cassidy, J.; Boni, C.; Cortes-Funes, H.; Cervantes, A.; Freyer, G.; et al. Leucovorin and Fluorouracil With or Without Oxaliplatin as First-Line Treatment in Advanced Colorectal Cancer. J. Clin. Oncol. 2000, 18, 2938-2947. [CrossRef]

75. Argyriou, A.A.; Cavaletti, G.; Briani, C.; Velasco, R.; Bruna, J.; Campagnolo, M.; Alberti, P.; Bergamo, F.; Cortinovis, D.; Cazzaniga M.E.; et al. Clinical pattern and associations of oxaliplatin acute neurotoxicity. Cancer 2012, 119, 438-444. [CrossRef] [PubMed]

76. Alejandro, L.M.; Behrendt, C.E.; Chen, K.; Openshaw, H.; Shibata, S. Predicting Acute and Persistent Neuropathy Associated With Oxaliplatin. Am. J. Clin. Oncol. 2013, 36, 331-337. [CrossRef] [PubMed]

77. Pulvers, J.N.; Marx, G. Factors associated with the development and severity of oxaliplatin-induced peripheral neuropathy: A systematic review. Asia-Pac. J. Clin. Oncol. 2017, 13, 345-355. [CrossRef] [PubMed]

78. Palugulla, S.; Thakkar, D.N.; Kayal, S.; Narayan, S.K.; Dkhar, S.A. Association of Voltage-Gated Sodium Channel Genetic Polymorphisms with Oxaliplatin-Induced Chronic Peripheral Neuropathy in South Indian Cancer Patients. Asian Pac. J. Cancer Prev. 2017, 18, 3157-3165. [PubMed]

79. Podratz, J.L.; Knight, A.M.; Ta, L.E.; Staff, N.P.; Gass, J.M.; Genelin, K.; Schlattau, A.; Lathroum, L.; Windebank, A.J. Cisplatin induced Mitochondrial DNA damage in dorsal root ganglion neurons. Neurobiol. Dis. 2011, 41, 661-668. [CrossRef] [PubMed]

80. Yang, Y.; Luo, L.; Cai, X.; Fang, Y.; Wang, J.; Chen, G.; Yang, J.; Zhou, Q.; Sun, X.; Cheng, X.; et al. Nrf2 inhibits oxaliplatin-induced peripheral neuropathy via protection of mitochondrial function. Free. Radic. Biol. Med. 2018, 120, 13-24. [CrossRef]

81. McQuade, R.M.; Stojanovska, V.; Bornstein, J.C.; Nurgali, K. PARP inhibition in platinum-based chemotherapy: Chemopotentiation and neuroprotection. Pharm. Res. 2018, 137, 104-113. [CrossRef] [PubMed]

82. Ranieri, G.; Laforgia, M.; Nardulli, P.; Ferraiuolo, S.; Molinari, P.; Marech, I.; Gadaleta, C.D. Oxaliplatin-Based Intra-arterial Chemotherapy in Colo-Rectal Cancer Liver Metastases: A Review from Pharmacology to Clinical Application. Cancers 2019, 11, 141. [CrossRef] [PubMed]

83. Joseph, E.K.; Chen, X.; Bogen, O.; Levine, J.D. Oxaliplatin Acts on IB4-Positive Nociceptors to Induce an Oxidative StressDependent Acute Painful Peripheral Neuropathy. J. Pain 2008, 9, 463-472. [CrossRef] [PubMed]

84. Mannelli, L.D.C.; Zanardelli, M.; Failli, P.; Ghelardini, C. Oxaliplatin-Induced Neuropathy: Oxidative Stress as Pathological Mechanism. Protective Effect of Silibinin. J. Pain 2012, 13, 276-284. [CrossRef]

85. Poupon, L.; Lamoine, S.; Pereira, V.; Barriere, D.A.; Lolignier, S.; Giraudet, F.; Aissouni, Y.; Meleine, M.; Prival, L.; Richard, D.; et al. Targeting the TREK-1 potassium channel via riluzole to eliminate the neuropathic and depressive-like effects of oxaliplatin. Neuropharmacol. 2018, 140, 43-61. [CrossRef]

86. Descoeur, J.; Pereira, V.; Pizzoccaro, A.; Francois, A.; Ling, B.; Maffre, V.; Couette, B.; Busserolles, J.; Courteix, C.; Noel, J.; et al. Oxaliplatininduced cold hypersensitivity is due to remodelling of ion channel expression in nociceptors. Embo Mol. Med. 2011, 3, 266-278. [CrossRef] [PubMed]

87. Dasari, S.; Tchounwou, P.B. Cisplatin in cancer therapy: Molecular mechanisms of action. Eur. J. Pharm. 2014, 740, 364-378. [CrossRef] [PubMed] 
88. Pereira, A.F.; De Oliveira, F.F.B.; Alves, B.W.D.F.; De Menezes, K.L.S.; De Mesquita, A.K.V.; Lisboa, M.R.P.; De Sousa, K.K.O.; Vale, M.L. Neurotoxic effect of oxaliplatin: Comparison with its oxalate-free analogue cis-[PtII(1R,2R-DACH)(3-acetoxy-1,1cyclobutanedicarboxylato)] (LLC-1402) in mice. Toxicol. Appl. Pharm. 2018, 340, 77-84. [CrossRef]

89. Fujita, S.; Hirota, T.; Sakiyama, R.; Baba, M.; Ieiri, I. Identification of drug transporters contributing to oxaliplatin-induced peripheral neuropathy. J. Neurochem. 2018, 148, 373-385. [CrossRef]

90. Janes, K.; Wahlman, C.; Little, J.W.; Doyle, T.; Tosh, D.K.; Jacobson, K.A.; Salvemini, D. Spinal neuroimmune activation is independent of T-cell infiltration and attenuated by A3 adenosine receptor agonists in a model of oxaliplatin-induced peripheral neuropathy. BrainBehav. Immun. 2015, 44, 91-99. [CrossRef]

91. Park, H.J.; Stokes, J.A.; Corr, M.; Yaksh, T.L. Toll-like receptor signaling regulates cisplatin-induced mechanical allodynia in mice. Cancer Chemother. Pharm. 2013, 73, 25-34. [CrossRef] [PubMed]

92. Xu, D.; Zhao, H.; Gao, H.; Zhao, H.; Liu, D.; Li, J. Participation of pro-inflammatory cytokines in neuropathic pain evoked by chemotherapeutic oxaliplatin via central GABAergic pathway. Mol. Pain 2018, 14. [CrossRef] [PubMed]

93. Li, Y.-Y.; Li, H.; Liu, Z.-L.; Li, Q.; Qiu, H.-W.; Zeng, L.-J.; Yang, W.; Zhang, X.-Z.; Li, Z.-Y. Activation of STAT3-mediated CXCL12 up-regulation in the dorsal root ganglion contributes to oxaliplatin-induced chronic pain. Mol. Pain 2017, 13. [CrossRef]

94. Wang, J.; Zhang, X.-S.; Tao, R.; Zhang, J.; Liu, L.; Jiang, Y.-H.; Ma, S.-H.; Song, L.-X.; Xia, L.-J. Upregulation of CX3CL1 mediated by NF- $\mathrm{B}$ activation in dorsal root ganglion contributes to peripheral sensitization and chronic pain induced by oxaliplatin administration. Mol. Pain 2017, 13. [CrossRef] [PubMed]

95. Jacobs, S.S.; Fox, E.; Dennie, C.; Morgan, L.B.; McCully, C.L.; Balis, F.M. Plasma and Cerebrospinal Fluid Pharmacokinetics of Intravenous Oxaliplatin, Cisplatin, and Carboplatin in Nonhuman Primates. Clin. Cancer Res. 2005, 11, 1669-1674. [CrossRef] [PubMed]

96. Branca, J.J.V.; Maresca, M.; Morucci, G.; Becatti, M.; Paternostro, F.; Gulisano, M.; Ghelardini, C.; Salvemini, D.; Mannelli, L.D.C.; Pacini, A. Oxaliplatin-induced blood brain barrier loosening: A new point of view on chemotherapy-induced neurotoxicity. Oncotarget 2018, 9, 23426-23438. [CrossRef] [PubMed]

97. Sanna, M.D.; Ghelardini, C.; Galeotti, N. Altered Expression of Cytoskeletal and Axonal Proteins in Oxaliplatin-Induced Neuropathy. Pharm. 2016, 97, 146-150. [CrossRef]

98. Popović, J.; Klajn, A.; Paunesku, T.; Ma, Q.; Chen, S.; Lai, B.; Stevanović, M.; Woloschak, G.E. Neuroprotective Role of Selected Antioxidant Agents in Preventing Cisplatin-Induced Damage of Human Neurons In Vitro. Cell. Mol. Neurobiol. 2019, 39, 619-636. [CrossRef] [PubMed]

99. Glimelius, B.; Manojlovic, N.; Pfeiffer, P.; Mosidze, B.; Kurteva, G.; Karlberg, M.; Mahalingam, D.; Jensen, P.B.; Kowalski, J.; Bengt, G.; et al. Persistent prevention of oxaliplatin-induced peripheral neuropathy using calmangafodipir (PledOx ${ }^{\circledR}$ ): A placebo-controlled randomised phase II study (PLIANT). Acta Oncol. 2017, 57, 393-402. [CrossRef] [PubMed]

100. Piechotta, V.; Jakob, T.; Langer, P.; Monsef, I.; Scheid, C.; Estcourt, L.J.; Ocheni, S.; Theurich, S.; Kuhr, K.; Scheckel, B.; et al. Multiple drug combinations of bortezomib, lenalidomide, and thalidomide for first-line treatment in adults with transplant-ineligible multiple myeloma: A network meta-analysis. Cochrane Database Syst. Rev. 2019. [CrossRef]

101. Oakervee, H.E.; Popat, R.; Curry, N.; Smith, P.; Morris, C.; Drake, M.; Agrawal, S.; Stec, J.; Schenkein, D.; Esseltine, D.-L.; et al. PAD combination therapy (PS-341/bortezomib, doxorubicin and dexamethasone) for previously untreated patients with multiple myeloma. Br. J. Haematol. 2005, 129, 755-762. [CrossRef] [PubMed]

102. Carozzi, V.A.; Renn, C.L.; Bardini, M.; Fazio, G.; Chiorazzi, A.; Meregalli, C.; Oggioni, N.; Shanks, K.; Quartu, M.; Serra, M.P.; et al. Bortezomib-Induced Painful Peripheral Neuropathy: An Electrophysiological, Behavioral, Morphological and Mechanistic Study in the Mouse. Plos One 2013, 8, e72995. [CrossRef] [PubMed]

103. Hu, B.; Zhou, Q.; Zhuang, L.; Yi, L.; Cao, J.; Wang, J.; Wu, T.; Yang, X. Efficacy and safety of subcutaneous versus intravenous bortezomib in multiple myeloma: A meta-analysis. Int. J. Clin. Pharm. 2017, 55, 329-338. [CrossRef]

104. Liu, H.; Xu, R.; Huang, H. Peripheral neuropathy outcomes and efficacy of subcutaneous bortezomib when combined with thalidomide and dexamethasone in the treatment of multiple myeloma. Exp. Med. 2016, 12, 3041-3046. [CrossRef] [PubMed]

105. Minarik, J.; Pavlicek, P.; Pour, L.; Pika, T.; Maisnar, V.; Spicka, I.; Jarkovsky, J.; Krejčí, M.; Bacovský, J.; Radocha, J.; et al Subcutaneous Bortezomib in Multiple Myeloma Patients Induces Similar Therapeutic Response Rates as Intravenous Application But It Does Not Reduce the Incidence of Peripheral Neuropathy. Plos One 2015, 10, e0123866. [CrossRef]

106. Peng, L.; Ye, X.; Zhou, Y.; Zhang, J.; Zhao, Q. Meta-analysis of incidence and risk of peripheral neuropathy associated with intravenous bortezomib. Support. Care Cancer 2015, 23, 2813-2824. [CrossRef] [PubMed]

107. Liu, Z.Q.; Xia, H.L.; Li, C.J.; Xia, L. Incidence and Risk of Peripheral Neuropathy Caused by Intravenous and Sub-cutaneous Injection of Bortezomib. Zhongguo Shi Yan Xue Ye Xue Za Zhi 2019, 27, 1654-1663. [CrossRef] [PubMed]

108. Saifee, T.; Elliott, K.J.; Lunn, M.P.T.; Blake, J.; Reilly, M.M.; Rabin, N.; Yong, K.; D'Sa, S.; Brandner, S. Bortezomib-induced inflammatory neuropathy. J. Peripher. Nerv. Syst. 2010, 15, 366-368. [CrossRef]

109. Stockstill, K.; Doyle, T.M.; Yan, X.; Chen, Z.; Janes, K.; Little, J.W.; Braden, K.; Lauro, F.; Giancotti, L.A.; Harada, C.M.; et al. Dysregulation of sphingolipid metabolism contributes to bortezomib-induced neuropathic pain. J. Exp. Med. 2018, 215, 1301-1313. [CrossRef] [PubMed]

110. Argyriou, A.A.; Iconomou, G.; Kalofonos, H.P. Bortezomib-induced peripheral neuropathy in multiple myeloma: A comprehensive review of the literature. Blood 2008, 112, 1593-1599. [CrossRef] [PubMed] 
111. Broyl, A.; Corthals, S.L.; Jongen, J.L.; Van Der Holt, B.; Kuiper, R.; De Knegt, Y.; Van Duin, M.; El Jarari, L.; Bertsch, U.; Lokhorst, H.M.; et al. Mechanisms of peripheral neuropathy associated with bortezomib and vincristine in patients with newly diagnosed multiple myeloma: A prospective analysis of data from the HOVON-65/GMMG-HD4 trial. Lancet Oncol. 2010, 11, 1057-1065. [CrossRef]

112. Magrangeas, F.; Kuiper, R.; Avet-Loiseau, H.; Gouraud, W.; Guérin-Charbonnel, C.; Ferrer, L.; Aussem, A.; Elghazel, H.; Suhard, J.; Der Sakissian, H.; et al. A Genome-Wide Association Study Identifies a Novel Locus for Bortezomib-Induced Peripheral Neuropathy in European Patients with Multiple Myeloma. Clin. Cancer Res. 2016, 22, 4350-4355. [CrossRef] [PubMed]

113. Alé, A.; Bruna, J.; Calls, A.; Karamita, M.; Haralambous, S.; Probert, L.; Navarro, X.; Udina, E. Inhibition of the neuronal NFkB pathway attenuates bortezomib-induced neuropathy in a mouse model. NeuroToxicology 2016, 55, 58-64. [CrossRef]

114. Wang, J.; Udd, K.A.; Vidisheva, A.; Swift, R.A.; Spektor, T.M.; Bravin, E.; Ibrahim, E.; Treisman, J.; Masri, M.; Berenson, J.R. Low serum vitamin D occurs commonly among multiple myeloma patients treated with bortezomib and/or thalidomide and is associated with severe neuropathy. Support. Care Cancer 2016, 24, 3105-3110. [CrossRef]

115. Garcia-Sanz, R.; Corchete-Sánchez, L.A.; Alcoceba, M.; Chillón, M.D.C.; Jiménez, C.; Prieto, I.; García-Álvarez, M.; Puig, N.; Rapado, I.; Barrio, S.; et al. Prediction of peripheral neuropathy in multiple myeloma patients receiving bortezomib and thalidomide: A genetic study based on a single nucleotide polymorphism array. Hematol. Oncol. 2016, 35, 746-751. [CrossRef] [PubMed]

116. Chaudhry, V.; Cornblath, D.R.; Polydefkis, M.; Ferguson, A.; Borrello, I. Characteristics of bortezomib- and thalidomide-induced peripheral neuropathy. J. Peripher. Nerv. Syst. 2008, 13, 275-282. [CrossRef] [PubMed]

117. Richardson, P.; Hideshima, T.; Anderson, K. Thalidomide in multiple myeloma. Biomed. Pharm. 2002, 56, 115-128. [CrossRef]

118. Wani, T.H.; Chakrabarty, A.; Shibata, N.; Yamazaki, H.; Guengerich, F.P.; Chowdhury, G. The Dihydroxy Metabolite of the Teratogen Thalidomide Causes Oxidative DNA Damage. Chem. Res. Toxicol. 2017, 30, 1622-1628. [CrossRef] [PubMed]

119. Wechalekar, A.; Chen, C.; Sutton, D.; Reece, D.; Voralia, M.; Stewart, A. Intermediate Dose Thalidomide (200 mg Daily) has Comparable Efficacy and Less Toxicity than Higher Doses in Relapsed Multiple Myeloma. Leuk. Lymphoma 2003, 44, 1147-1149. [CrossRef] [PubMed]

120. Prince, H.M.; Schenkel, B.; Mileshkin, L. An analysis of clinical trials assessing the efficacy and safety of single-agent thalidomide in patients with relapsed or refractory multiple myeloma. Leuk. Lymphoma 2007, 48, 46-55. [CrossRef] [PubMed]

121. Johnson, D.C.; Corthals, S.L.; A Walker, B.; Ross, F.M.; Gregory, W.M.; Dickens, N.J.; Lokhorst, H.M.; Goldschmidt, H.; Davies, F.E.; Durie, B.G.; et al. Genetic Factors Underlying the Risk of Thalidomide-Related Neuropathy in Patients With Multiple Myeloma. J. Clin. Oncol. 2011, 29, 797-804. [CrossRef] [PubMed]

122. Lopus, M.; Smiyun, G.; Miller, H.; Oroudjev, E.; Wilson, L.; Jordan, M.A. Mechanism of action of ixabepilone and its interactions with the BIII-tubulin isotype. Cancer Chemother. Pharm. 2015, 76, 1013-1024. [CrossRef] [PubMed]

123. Sandier, S.G.; Tobin, W.; Henderson, E.S. Vincristine-induced neuropathy: A clinical study of fifty leukemic patients. Neurol. 1969, 19, 367. [CrossRef]

124. Boyette-Davis, J.A.; Hou, S.; Abdi, S.; Dougherty, P.M. An updated understanding of the mechanisms involved in chemotherapyinduced neuropathy. Pain Manag. 2018, 8, 363-375. [CrossRef]

125. Casey, E.B.; Jellife, A.M.; Le Quesne, P.M.; Millett, Y.L. Vincristine neuropathy. Brain 1973, 96, 69-86. [CrossRef] [PubMed]

126. Scalone, S.; Sorio, R.; Bortolussi, R.; Lombardi, D.; La Mura, N.; Veronesi, A. Vinorelbine-induced acute reversible peripheral neuropathy in a patient with ovarian carcinoma pretreated with carboplatin and paclitaxel. Acta Oncol. 2004, 43, 209-211. [CrossRef] [PubMed]

127. Kourie, H.R.; Mavroudakis, N.; Aftimos, P.; Piccart, M. Charcot-Marie-Tooth hereditary neuropathy revealed after administration of docetaxel in advanced breast cancer. World J. Clin. Oncol. 2017, 8, 425-428. [CrossRef] [PubMed]

128. Diouf, B.; Crews, K.R.; Lew, G.; Pei, D.; Cheng, C.; Bao, J.; Zheng, J.J.; Yang, W.; Fan, Y.; Wheeler, H.E.; et al. Association of an Inherited Genetic Variant With Vincristine-Related Peripheral Neuropathy in Children With Acute Lymphoblastic Leukemia. JAMA 2015, 313, 815-823. [CrossRef] [PubMed]

129. Bhat, K.G.; Singhal, V.; Borker, A.S. Successful treatment of vincristine induced ptosis and polyneuropathy with pyridoxine and pyridostigmine in a child with acute lymphoblastic leukemia. Indian J. Med Paediatr. Oncol. Off. J. Indian Soc. Med Paediatr. Oncol. 2012, 33, 185-187. [CrossRef]

130. Halat, K.M.; Dennehy, C.E. Botanicals and dietary supplements in diabetic peripheral neuropathy. J. Am. Board Fam. Pr. 2003, 16, 47-57. [CrossRef] [PubMed]

131. Ranieri, G.; Gadaleta-Caldarola, G.; Goffredo, V.; Patruno, R.; Mangia, A.; Rizzo, A.; Sciorsci, R.L.; Gadaleta, C.D. Sorafenib (BAY 43-9006) in Hepatocellular Carcinoma Patients: From Discovery to Clinical Development. Curr. Med. Chem. 2012, 19, 938-944. [CrossRef] [PubMed]

132. Diezi, M.; Buclin, T.; Kuntzer, T. Toxic and drug-induced peripheral neuropathies. Curr. Opin. Neurol. 2013, $26,481-488$. [CrossRef] [PubMed]

133. Timmins, H.C.; Li, T.; Kiernan, M.C.; Horvath, L.G.; Goldstein, D.; Park, S.B. Quantification of Small Fiber Neuropathy in Chemotherapy-Treated Patients. J. Pain 2020, 21, 44-58. [CrossRef] [PubMed]

134. Speck, R.M.; Sammel, M.D.; Farrar, J.T.; Hennessy, S.; Mao, J.J.; Stineman, M.G.; DeMichele, A. Impact of Chemotherapy-Induced Peripheral Neuropathy on Treatment Delivery in Nonmetastatic Breast Cancer. J. Oncol. Pr. 2013, 9, e234-e240. [CrossRef] [PubMed] 
135. Hong, J.; Tian, J.; Wu, L. The influence of chemotherapyinduced neurotoxicity on psychological distress and sleep disturbance in cancer patients. Curr. Oncol. 2014, 21, 174-180. [CrossRef] [PubMed]

136. Kandula, T.; Farrar, M.A.; Kiernan, M.C.; Krishnan, A.V.; Goldstein, D.; Horvath, L.; Grimison, P.; Boyle, F.; Baron-Hay, S.; Park, S.B. Neurophysiological and clinical outcomes in chemotherapy-induced neuropathy in cancer. Clin. Neurophysiol. 2017, 128, 1166-1175. [CrossRef] [PubMed]

137. Boyette-Davis, J.; Xin, W.; Zhang, H.; Dougherty, P.M. Intraepidermal nerve fiber loss corresponds to the development of Taxol-induced hyperalgesia and can be prevented by treatment with minocycline. Pain 2011, 152, 308-313. [CrossRef] [PubMed]

138. Ferrari, G.; Nallasamy, N.; Downs, H.; Dana, R.; Oaklander, A.L. Corneal innervation as a window to peripheral neuropathies. Exp. Eye Res. 2013, 113, 148-150. [CrossRef] [PubMed]

139. Kerckhove, N.; Collin, A.; Condé, S.; Chaleteix, C.; Pezet, D.; Balayssac, D. Long-Term Effects, Pathophysiological Mechanisms, and Risk Factors of Chemotherapy-Induced Peripheral Neuropathies: A Comprehensive Literature Review. Front. Pharm. 2017, 8, 86. [CrossRef]

140. Haroutounian, S.; Nikolajsen, L.; Bendtsen, T.F.; Finnerup, N.B.; Kristensen, A.D.; Hasselstrøm, J.B.; Jensen, T.S. Primary afferent input critical for maintaining spontaneous pain in peripheral neuropathy. Pain 2014, 155, 1272-1279. [CrossRef] [PubMed]

141. Areti, A.; Yerra, V.G.; Naidu, V.; Kumar, A. Oxidative stress and nerve damage: Role in chemotherapy induced peripheral neuropathy. Redox Biol. 2014, 2, 289-295. [CrossRef]

142. Doyle, T.; Chen, Z.; Muscoli, C.; Bryant, L.; Esposito, E.; Cuzzocrea, S.; Dagostino, C.; Ryerse, J.; Rausaria, S.; Kamadulski, A.; et al Targeting the Overproduction of Peroxynitrite for the Prevention and Reversal of Paclitaxel-Induced Neuropathic Pain. J. Neurosci. 2012, 32, 6149-6160. [CrossRef]

143. Mironov, S.L.; Ivannikov, M.V.; Johansson, M. [Ca2+] Signaling between Mitochondria and Endoplasmic Reticulum in Neurons Is Regulated by Microtubules. J. Biol. Chem. 2005, 280, 715-721. [CrossRef] [PubMed]

144. Siau, C.; Bennett, G.J. Dysregulation of Cellular Calcium Homeostasis in Chemotherapy-Evoked Painful Peripheral Neuropathy. Anesth. Analg. 2006, 102, 1485-1490. [CrossRef] [PubMed]

145. Aromolaran, K.A.; A Goldstein, P. Ion channels and neuronal hyperexcitability in chemotherapy-induced peripheral neuropathy. Mol. Pain 2017, 13, 1744806917714693. [CrossRef] [PubMed]

146. Gutiérrez-Gutiérrez, G.; Sereno, M.; Miralles, A.; Casado-Sáenz, E.; Gutiérrez-Rivas, E. Chemotherapy-induced peripheral neuropathy: Clinical features, diagnosis, prevention and treatment strategies. Clin. Transl. Oncol. 2010, 12, 81-91. [CrossRef] [PubMed]

147. Chien, T.-J.; Liu, C.-Y.; Fang, C.-J.; Kuo, C.-Y. The Efficacy of Acupuncture in Chemotherapy-Induced Peripheral Neuropathy: Systematic Review and Meta-Analysis. Integr. Cancer. 2019, 18, 1534735419886662. [CrossRef] [PubMed]

148. Krukowski, K.; Eijkelkamp, N. CD8+ T Cells and Endogenous IL-10 Are Required for Resolution of Chemothera-py-Induced Neuropathic Pain. J. Neurosci. 2016, 36, 11074-11083. [CrossRef] [PubMed]

149. Hershman, D.L.; Lacchetti, C.; Dworkin, R.H.; Smith, E.M.L.; Bleeker, J.; Cavaletti, G.; Chauhan, C.; Gavin, P.; Lavino, A.; Lustberg, M.B.; et al. Prevention and Management of Chemotherapy-Induced Peripheral Neuropathy in Survivors of Adult Cancers: American Society of Clinical Oncology Clinical Practice Guideline. J. Clin. Oncol. 2014, 32, 1941-1967. [CrossRef] [PubMed]

150. Smith, E.M.L.; Pang, H.; Cirrincione, C.; Fleishman, S.; Paskett, E.D.; Ahles, T.; Bressler, L.R.; Fadul, C.E.; Knox, C.; Le-Lindqwister, N.; et al. Effect of Duloxetine on Pain, Function, and Quality of Life Among Patients With Chemotherapy-Induced Painful Peripheral Neuropathy. JAMA 2013, 309, 1359-1367. [CrossRef] [PubMed]

151. Visovsky, C.G.; Collins, M.; Abbott, L.; Aschenbrenner, J.; Hart, C. Putting Evidence Into Practice ${ }^{\circledR}$ : Evidence-Based Interventions for Chemotherapy-Induced Peripheral Neuropathy. Clin. J. Oncol. Nurs. 2007, 11, 901-913. [CrossRef] [PubMed]

152. Moulin, D.; Boulanger, A.; Clark, A.J.; Clarke, H.; Dao, T.; A Finley, G.; Furlan, A.; Gilron, I.; Gordon, A.; Morley-Forster, P.K.; et al. Pharmacological Management of Chronic Neuropathic Pain: Revised Consensus Statement from the Canadian Pain Society. Pain Res. Manag. 2014, 19, 328-335. [CrossRef] [PubMed]

153. Gewandter, J.S.; Mohile, S.G.; Heckler, C.E.; Ryan, J.L.; Kirshner, J.J.; Flynn, P.J.; Hopkins, J.O.; Morrow, G.R. A phase III randomized, placebo-controlled study of topical amitriptyline and ketamine for chemotherapy-induced peripheral neuropathy (CIPN): A University of Rochester CCOP study of 462 cancer survivors. Support. Care Cancer 2014, 22, 1807-1814. [CrossRef] [PubMed]

154. Barton, D.; Wos, E.J.; Qin, R.; Mattar, B.I.; Green, N.B.; Lanier, K.S.; Bearden, J.D.; Kugler, J.W.; Hoff, K.L.; Reddy, P.S.; et al. A double-blind, placebo-controlled trial of a topical treatment for chemotherapy-induced peripheral neuropathy: NCCTG trial N06CA. Support. Care Cancer 2010, 19, 833-841. [CrossRef] [PubMed]

155. Fallon, M.; Storey, D.J.; Krishan, A.; Weir, C.J.; Mitchell, R.; Fleetwoodwalker, S.M.; Scott, A.C.; Colvin, L. Cancer treatment-related neuropathic pain: Proof of concept study with menthol—a TRPM8 agonist. Support. Care Cancer 2015, 23, 2769-2777. [CrossRef] [PubMed]

156. Ali, M.M.; Moeller, M.; Rybicki, L.; Moore, H.C.F. Long-term peripheral neuropathy symptoms in breast cancer survivors. Breast Cancer Res. Treat. 2017, 166, 519-526. [CrossRef]

157. Park, S.B.; Goldstein, D.; Krishnan, A.V.; Lin, C.S.-Y.; Friedlander, M.L.; Cassidy, J.; Koltzenburg, M.; Kiernan, M.C. Chemotherapyinduced peripheral neurotoxicity: A critical analysis. Ca: A Cancer J. Clin. 2013, 63, 419-437. [CrossRef] 
158. Hausheer, F.; Schilsky, R.L.; Bain, S.; Berghorn, E.J.; Lieberman, F. Diagnosis, Management, and Evaluation of ChemotherapyInduced Peripheral Neuropathy. Semin. Oncol. 2006, 33, 15-49. [CrossRef] [PubMed]

159. Argyriou, A.; Kyritsis, A.P.; Makatsoris, T.; Kalofonos, H.P. Chemotherapy-induced peripheral neuropathy in adults: A comprehensive update of the literature. Cancer Manag. Res. 2014, 6, 135-147. [CrossRef]

160. Canta, A.; Pozzi, E.; Carozzi, V.A. Mitochondrial Dysfunction in Chemotherapy-Induced Peripheral Neuropathy (CIPN). Toxics 2015, 3, 198-223. [CrossRef] [PubMed]

161. Loizzi, V.; Ranieri, G.; Laforgia, M.; Gadaleta, C.D.; Gargano, G.; Kardhashi, A.; De Liso, M.; Naglieri, E.; Del Vecchio, V.; Cicinelli, E.; et al. PARP inhibitors and epithelial ovarian cancer: Molecular mechanisms, clinical development and future prospective (Review). Oncol. Lett. 2020, 20, 1. [CrossRef] [PubMed]

162. Valko, H.M.A.M.T.C.M.; Morris, H.; Cronin, M.T.D. Metals, Toxicity and Oxidative Stress. Curr. Med. Chem. 2005, 12, 1161-1208. [CrossRef] [PubMed]

163. Wang, J.T.; Medress, Z.A.; Barres, B.A. Axon degeneration: Molecular mechanisms of a self-destruction pathway. J. Cell Biol. 2012, 196, 7-18. [CrossRef] [PubMed]

164. Lees, J.G.; Makker, P.G.; Tonkin, R.S.; Abdulla, M.; Park, S.B.; Goldstein, D.; Moalem-Taylor, G. Immune-mediated processes implicated in chemotherapy-induced peripheral neuropathy. Eur. J. Cancer 2017, 73, 22-29. [CrossRef] [PubMed]

165. Warwick, R.; Hanani, M. The contribution of satellite glial cells to chemotherapy-induced neuropathic pain. Eur. J. Pain 2012, 17, 571-580. [CrossRef] [PubMed]

166. Li, C.; Deng, T.; Shang, Z.; Wang, D.; Xiao, Y. Blocking TRPA1 and TNF- $\alpha$ Signal Improves Bortezomib-Induced Neuropathic Pain. Cell. Physiol. Biochem. 2018, 51, 2098-2110. [CrossRef]

167. Jin, X. Acute p38-Mediated Modulation of Tetrodotoxin-Resistant Sodium Channels in Mouse Sensory Neurons by Tumor Necrosis Factor-. J. Neurosci. 2006, 26, 246-255. [CrossRef] [PubMed]

168. Dietrich, J.; Prust, M.; Kaiser, J. Chemotherapy, cognitive impairment and hippocampal toxicity. Neurosci. 2015, 309, $224-232$. [CrossRef]

169. Horky, L.L.; Gerbaudo, V.H.; Zaitsev, A.; Plesniak, W.; Hainer, J.; Govindarajulu, U.; Kikinis, R.; Dietrich, J. Systemic chemotherapy decreases brain glucose metabolism. Ann. Clin. Transl. Neurol. 2014, 1, 788-798. [CrossRef] [PubMed]

170. Janelsins, M.C.; Kohli, S.; Mohile, S.G.; Usuki, K.; Ahles, T.A.; Morrow, G.R. An Update on Cancer- and Chemotherapy-Related Cognitive Dysfunction: Current Status. Semin. Oncol. 2011, 38, 431-438. [CrossRef]

171. Nudelman, K.N.; McDonald, B.C.; Wang, Y.; Smith, D.J.; West, J.D.; O’Neill, D.P.; Zanville, N.R.; Champion, V.L.; Schneider, B.P.; Saykin, A.J. Cerebral Perfusion and Gray Matter Changes Associated With Chemotherapy-Induced Peripheral Neuropathy. J. Clin. Oncol. 2016, 34, 677-683. [CrossRef] [PubMed]

172. Rochfort, K.D.; Collins, L.E.; Murphy, R.P.; Cummins, P.M. Downregulation of Blood-Brain Barrier Phenotype by Proinflammatory Cytokines Involves NADPH Oxidase-Dependent ROS Generation: Consequences for Interendothelial Adherens and Tight Junctions. Plos One 2014, 9, e101815. [CrossRef] [PubMed]

173. Argaw, A.T.; Zhang, Y.; Snyder, B.J.; Zhao, M.-L.; Kopp, N.; Lee, S.C.; Raine, C.S.; Brosnan, C.F.; John, G.R. IL-1 $\beta$ Regulates Blood-Brain Barrier Permeability via Reactivation of the Hypoxia-Angiogenesis Program. J. Immunol. 2006, 177, 5574-5584. [CrossRef] [PubMed]

174. Hou, S.; Huh, B.; Kim, H.K.; Kim, K.H.; Abdi, S. Treatment of Chemotherapy-Induced Peripheral Neuropathy: Systematic Review and Recommendations. Pain Physician 2018, 21, 571-592. [PubMed]

175. Schloss, J.M.; Colosimo, M.; Airey, C.; Masci, P.P.; Linnane, A.W.; Vitetta, L. Nutraceuticals and chemotherapy induced peripheral neuropathy (CIPN): A systematic review. Clin. Nutr. 2013, 32, 888-893. [CrossRef] [PubMed]

176. Hu, L.-Y.; Mi, W.-L.; Wu, G.-C.; Wang, Y.-Q.; Mao-Ying, Q.-L. Prevention and Treatment for Chemotherapy-Induced Peripheral Neuropathy: Therapies Based on CIPN Mechanisms. Curr. Neuropharmacol. 2019, 17, 184-196. [CrossRef]

177. Movsas, B.; Scott, C.; Langer, C.J.; Werner-Wasik, M.; Nicolaou, N.; Komaki, R.; Machtay, M.; Smith, C.; Axelrod, R.; Sarna, L.; et al. Randomized Trial of Amifostine in Locally Advanced Non-Small-Cell Lung Cancer Patients Receiving Chemotherapy and Hyperfractionated Radiation: Radiation Therapy Oncology Group Trial 98-01. J. Clin. Oncol. 2005, 23, 2145-2154. [CrossRef] [PubMed]

178. Stehr, J.E.; Lundström, I.; Karlsson, J.O.G. Evidence that fodipir (DPDP) binds neurotoxic Pt2+ with a high affinity: An electron paramagnetic resonance study. Sci. Rep. 2019, 9, 1-9. [CrossRef] [PubMed]

179. Dawkins, J.L.; Hulme, D.J.; Brahmbhatt, S.B.; Auer-Grumbach, M.; Nicholson, G.A. Mutations in SPTLC1, encoding serine palmitoyltransferase, long chain base subunit-1, cause hereditary sensory neuropathy type I. Nat. Genet. 2001, 27, 309-312. [CrossRef] [PubMed]

180. Fernyhough, P.; Smith, D.R.; Schapansky, J.; Van Der Ploeg, R.; Gardiner, N.J.; Tweed, C.W.; Kontos, A.; Freeman, L.; Purves-Tyson, T.D.; Glazner, G.W. Activation of Nuclear Factor-B via Endogenous Tumor Necrosis Factor Regulates Survival of Axotomized Adult Sensory Neurons. J. Neurosci. 2005, 25, 1682-1690. [CrossRef] [PubMed]

181. Mohty, B.; El-Cheikh, J.; Yakoub-Agha, I.; Moreau, P.; Harousseau, J.-L.; Mohty, M. Peripheral neuropathy and new treatments for multiple myeloma: Background and practical recommendations. Haematol. 2010, 95, 311-319. [CrossRef]

182. Morawska, M.; Grzasko, N.; Kostyra, M.; Wojciechowicz, J.; Hus, M. Therapy-related peripheral neuropathy in multiple myeloma patients. Hematol. Oncol. 2014, 33, 113-119. [CrossRef] [PubMed] 
183. Ebenezer, G.J.; Carlson, K.; Donovan, D.; Cobham, M.; Chuang, E.; Moore, A.; Cigler, T.; Ward, M.; Lane, M.E.; Ramnarain, A.; et al. Ixabepilone-induced mitochondria and sensory axon loss in breast cancer patients. Ann. Clin. Transl. Neurol. 2014, 1, 639-649. [CrossRef] [PubMed]

184. Topp, K.S.; Tanner, K.D.; Levine, J.D. Damage to The Cytoskeleton of Large Diameter Sensory Neurons and Myelin-ated Axons in Vincristine-Induced Painful Peripheral Neuropathy in The Rat. J. Comp. Neurol. 2000, 424, 563-576. [CrossRef]

185. Wolfe, G.I.; Trivedi, J.R. Painful peripheral neuropathy and its nonsurgical treatment. Muscle Nerve 2004, 30, 3-19. [CrossRef] [PubMed]

186. Olesen, L.L.; Jensen, T.S. Prevention and Management of Drug-Induced Peripheral Neuropathy. Drug Saf. 1991, 6, 302-314. [CrossRef] [PubMed]

187. Posner, I.; Engel, M.; Gazit, A.; Levitzki, A. Kinetics of inhibition by tyrphostins of the tyrosine kinase activity of the epidermal growth factor receptor and analysis by a new computer program. Mol. Pharmacol. 1994, 45, 673-683. [PubMed]

188. Polier, S.; Samant, R.S.; Clarke, P.A.; Workman, P.; Prodromou, C.; Pearl, L.H. ATP-competitive inhibitors block protein kinase recruitment to the Hsp90-Cdc37 system. Nat. Chem. Biol. 2013, 9, 307-312. [CrossRef]

189. Ranieri, G.; Marech, I.; Niccoli-Asabella, A.; Di Palo, A.; Porcelli, M.; Lavelli, V.; Rubini, G.; Ferrari, C.; Gadaleta, P. Tyrosine-Kinase Inhibitors Therapies with Mainly Anti-Angiogenic Activity in Advanced Renal Cell Carcinoma: Value of PET/CT in Response Evaluation. Int. J. Mol. Sci. 2017, 18, 1937. [CrossRef] [PubMed]

190. Ranieri, G.; Mammì, M.; Di Paola, E.D.; Russo, E.; Gallelli, L.; Citraro, R.; Gadaleta, C.D.; Marech, I.; Ammendola, M.; De Sarro, G. Pazopanib a tyrosine kinase inhibitor with strong anti-angiogenetic activity: A new treatment for metastatic soft tissue sarcoma. Crit. Rev. Oncol. 2014, 89, 322-329. [CrossRef]

191. Ranieri, G.; Pantaleo, M.; Piccinno, M.; Roncetti, M.; Mutinati, M.; Marech, I.; Patruno, R.; Rizzo, A.; Sciorsci, R.L. Tyrosine kinase inhibitors (TKIs) in human and pet tumours with special reference to breast cancer: A comparative review. Crit. Rev. Oncol. 2013, 88, 293-308. [CrossRef] [PubMed]

192. Laforgia, M.; Marech, I.; Nardulli, P.; Calabrò, C.; Gadaleta, C.D.; Ranieri, G. An evaluation of masitinib for treating systemic mastocytosis. Expert Opin. Pharm. 2019, 20, 1539-1550. [CrossRef] [PubMed]

193. Marech, I.; Patruno, R.; Zizzo, N.; Gadaleta, C.; Introna, M.; Zito, A.F.; Gadaleta, C.D.; Ranieri, G. Masitinib (AB1010), from canine tumor model to human clinical development: Where we are? Crit. Rev. Oncol. 2014, 91, 98-111. [CrossRef] [PubMed]

194. Laforgia, M.; Calabrò, C.; Scattone, A.; LaFace, C.; Porcelli, M.; Gadaleta, C.D.; Nardulli, P.; Ranieri, G. Pharmacotherapy in Mast Cell Leukemia. Expert Opin. Pharm. 2020, 21, 1059-1069. [CrossRef] [PubMed]

195. Gadaleta-Caldarola, G.; Infusino, S.; Galise, I.; Ranieri, G.; Vinciarelli, G.; Fazio, V.; Divella, R.; Daniele, A.; Filippelli, G.; Gadaleta, C.D. Sorafenib and locoregional deep electro-hyperthermia in advanced hepatocellular carcinoma: A phase II study. Oncol. Lett. 2014, 8, 1783-1787. [CrossRef]

196. Ranieri, G.; LaFace, C.; Laforgia, M.; De Summa, S.; Porcelli, M.; Macina, F.; Ammendola, M.; Molinari, P.; Lauletta, G.; Di Palo, A.; et al. Bevacizumab Plus FOLFOX-4 Combined With Deep Electro-Hyperthermia as First-line Therapy in Metastatic Colon Cancer: A Pilot Study. Front. Oncol. 2020, 10, 590707. [CrossRef] [PubMed]

197. Verheyen, A.; Peeraer, E.; Nuydens, R.; Dhondt, J.; Poesen, K.; Pintelon, I.; Daniels, A.; Timmermans, J.-P.; Meert, T.; Carmeliet, P.; et al. Systemic anti-vascular endothelial growth factor therapies induce a painful sensory neuropathy. Brain 2012, 135, $2629-2641$. [CrossRef] [PubMed]

198. Saad, M.; Psimaras, D.; Tafani, C.; Sallansonnet-Froment, M.; Calvet, J.-H.; Vilier, A.; Tigaud, J.-M.; Bompaire, F.; Lebouteux, M.; De Greslan, T.; et al. Quick, non-invasive and quantitative assessment of small fiber neuropathy in patients receiving chemotherapy. J. Neuro-Oncol. 2016, 127, 373-380. [CrossRef]

199. Chiaramonte, R.; Romano, M.; Vecchio, M. A Systematic Review of the Diagnostic Methods of Small Fiber Neuropathies in Rehabilitation. Diagn. 2020, 10, 613. [CrossRef] [PubMed]

200. Vecchio, M.; Chiaramonte, R.; Romano, M.; Pavone, P.; Musumeci, G.; Mauro, G.L. A Systematic Review of Pharmacologic and Rehabilitative Treatment of Small Fiber Neuropathies. Diagn. 2020, 10, 1022. [CrossRef] [PubMed]

201. Chua, K.C.; Kroetz, D.L. Genetic advances uncover mechanisms of chemotherapy-induced peripheral neuropathy. Clin. Pharm. 2016, 101, 450-452. [CrossRef] [PubMed] 